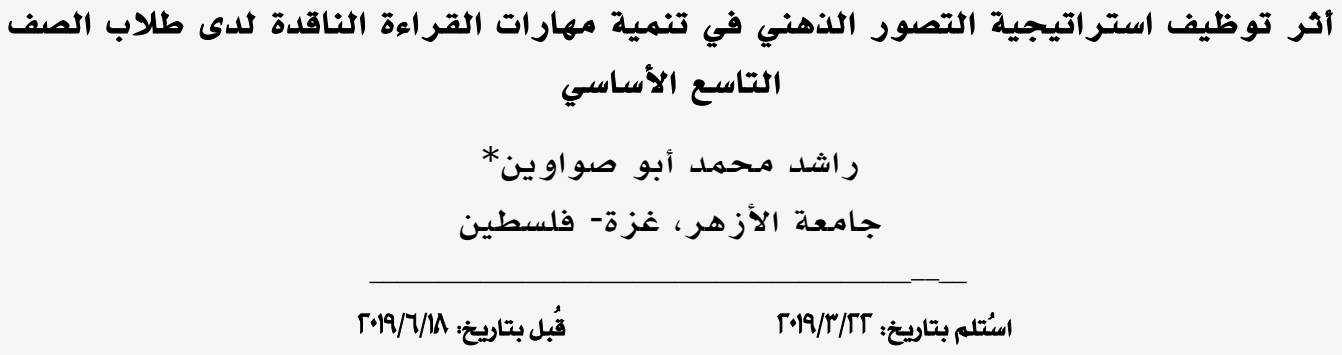

The Effect of Using Mental Imagination Strategy on Developing Critical Reading Skills among Ninth Graders

Rashed M. Abu Soawen*

Al-Azhar university-Gaza, Palestine

Abstract The study aimed at showing the effect of using Mental Imagination strategy in developing critical reading skills for ninth grade students in Gaza. The study used the experimental method and suitable critical reading skills for nine grade were identified. The sample of the study consisted of 81 students (ninth grade) distributed to an experimental group (41 students) and a controlled group (40 student), reading subjects were taught to the experimental group by using the Mental Imagination strategy which was applied by a teacher who received training related to this strategy. The controlled group were taught by using traditional methods. After a test was implemented to measure the critical reading skills and conducting statistical treatments by using Ancova, the study revealed that there was an effect on using the Mental Imagination strategy in developing targeted critical reading skills. It also clarified that there were significant differences at $a \leq 0.01$ between the experimental and controlled group grades in the post test of critical reading skills attributed to the experimental group.

Keywords: Strategy, mental imagination, critical reading, nine grade.

*faleet2000@hotmail.com 
الهقروء، و تفسير دلالاتـهـ تفسـيرًا منطقيّا

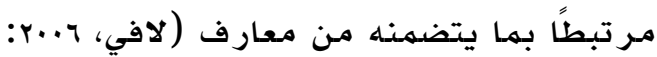

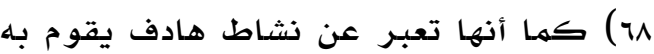

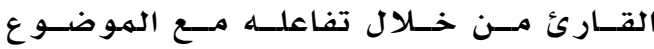
الهقروء، بغية تذكر جزئياته، و فهم معنــاه،

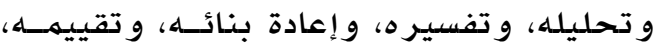

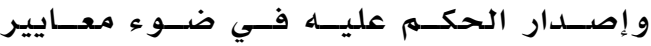

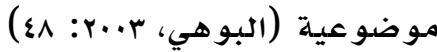

و لقد تزايد الاهتمام بالقراءة الناقدة نتيجلة

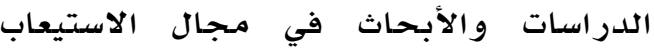
القرائي، والمهارات التفكيرية التي تجعل مهمهة القارئ الناقد أكثر نشاطًا ورتعقيدًا، فيزداد التركيز على ضرورة امتلاك القارئ لهمهار ات أوسـع و معار ف وخبر ات سـابقة حول النص الهطلوب نقده، وضرورة توظيف الههارات و المعارف و الخبر ات في أي مجال قرائي، و ليس فقط ضمن الهمنهج الدراسي

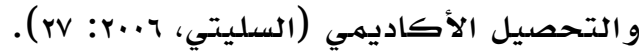
وتعد القـراءة الناقــدة عمليـة تفاعـل بـيـن القارئ و النص، يفحص فيها القارئ بخبر اته، و معارفه ما يتضــمنـه الـنص مسـن إيحسـاءات،

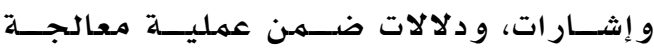
الهقروء؛ و لا يخفى ما تتطلبـه هذه العمليـة

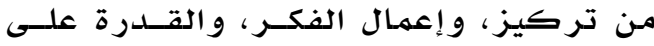

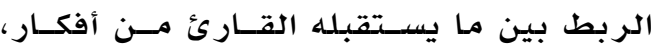
وبين تعلهــه السـابق السذي اكتسـبـه، كمــا تتطلب درجة عاليــة مــن الـوعي، والنظــرة

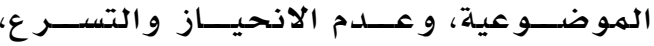
و محاو للة كشف الحقيقة، وتقويم الهقروء، وبالتالي فإن القراءة الناقدة عمليـة تتكـون من عدة عمليات، و ليست عملية و احدة، فهـي

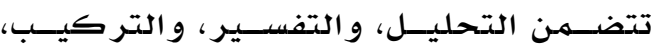

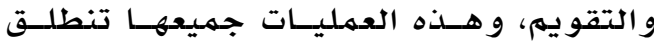
وتتمهحور حـول الفهـهم السـذي يعـــ أسـاسـهـا

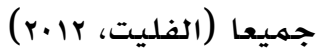

وهذه العمليات التي يمار سها القـارئ عنــدما تكون القراءة بهدف النقد، يمكــن توضـيـحها

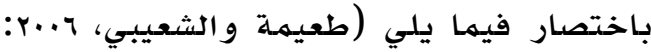
$:(1 \cdot r$
تعد القراءة مـن الأدوات الرئيسـة لتحصـيل الهعارف و الخبـرات، و من أبرز الوسائل التي يطل من خلالها الفرد على الفكر ، والثقافات

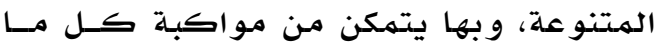
هو جديد في عالم المعرفة، فتنهــو خبـر اتسه

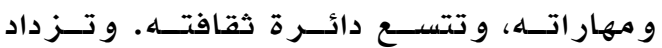
أهميلة القـر اءة فـي العصــر الحسـالي نتيجــة

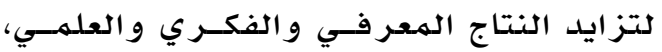
مهما يستلذزم مـن الفرد التفاعـل بكفــاءة مــع

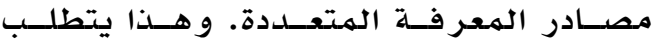
الاهتمام بتحسين تعليهم القراءة بمسـتوياتها المختلفة لا سيما المستو يات المتقدمسة بهـا تتضمنه مـن و عي و تحليل و نقد و تقويهم. و تكتسب إجـادة مهارات القــر اءة بمســتوياتها المتنو عة أهميتها مـن كونها متطلبـا أسـاسـيا للنجاح، ليس فقط في التعلهم اللغوي، وإنهـا في تعلم المواد العلميــة الأخــرى، إذ تثــير

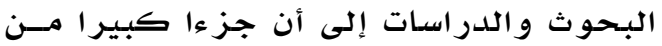

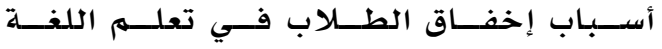
و مهاراتها، و فهم المسـائل الرياضية وابه العلميلة يعود إلى ضعفهم في التمكن مسـن الههــارات

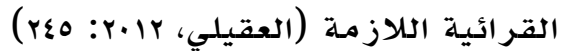
و تعتبـر القــر اءة الناقــدة إحـــى المســتويـات

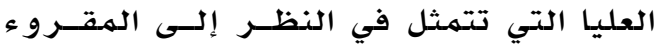

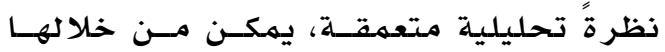
معرفة التفاصسيل الدقيقسة لكسل مـا يواجـهـ

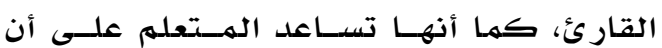
يصبح متفتح العقل، وأن يحترم وجهات نظر

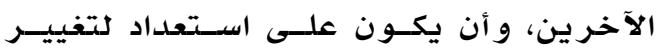

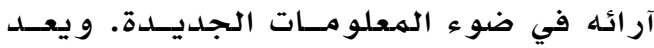

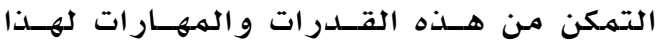

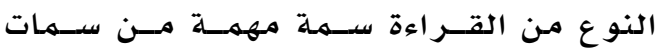
القارئ الجيد، تسهم في تمكينه مــن إصــــار

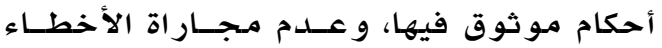

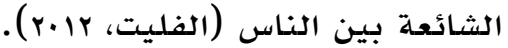
و في ضوء ذلك فإن القراءة الناقـدة تعتبــر عملية تقويهم للهمادة الهقرووة، و الحكمم عليها

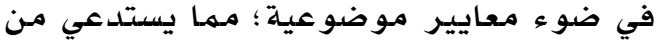

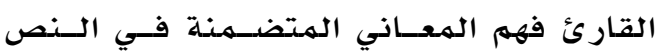




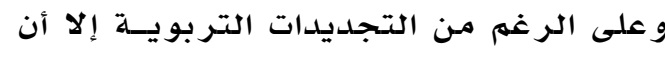

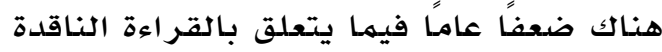
و إتقان مهاراتها، ووفي هـــا السـيـاق أشــارت

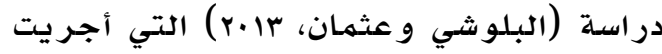

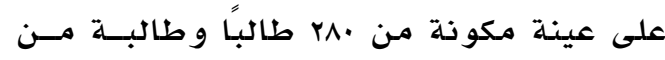

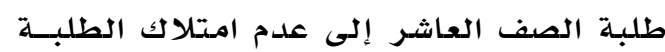

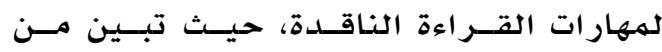

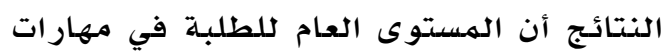

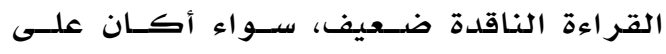

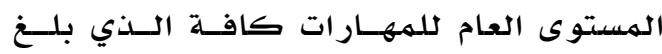

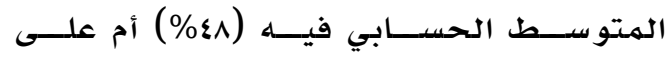
مستوى كل مهارة على حدة.

وتبين من نتـائج تطبيـق الاختبــار الــوطني

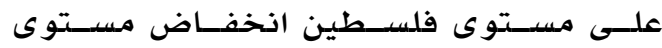

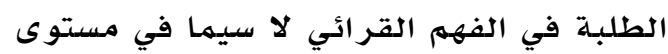

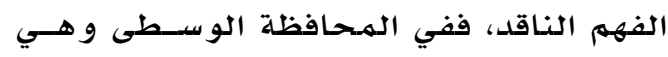

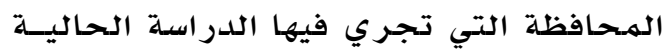

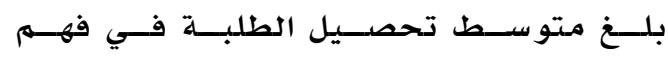

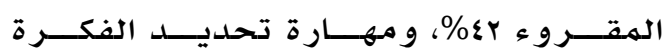

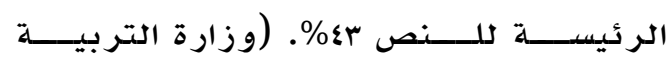

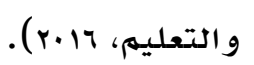

و لهم تقف الدراسات عند حد التشخيص، فلقد اتجهـت العديـد مــن الدر اســات إلـى تنـميسة

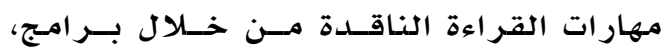

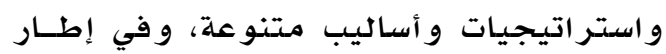

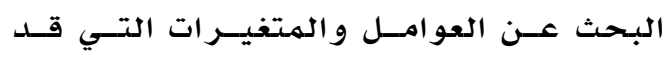
تسهـم في تحسـيـن أداء الطلبــة فــي القــر اءة

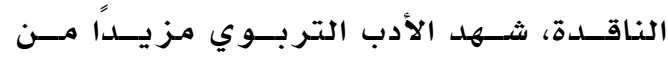

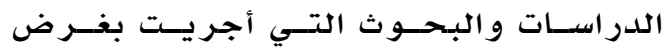

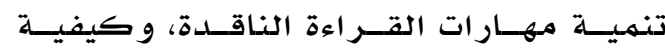

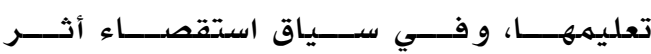

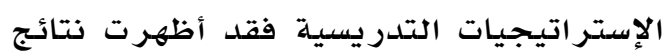

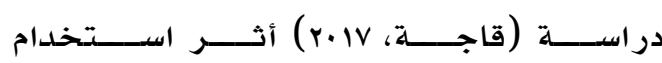

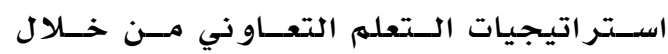

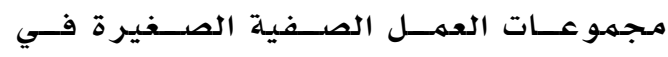

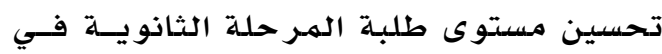
اكتساب مهار ات القر اءة الناقدة.

و أثـارت دراسـة (الحوامدة، 10+r) إلى فاعلية

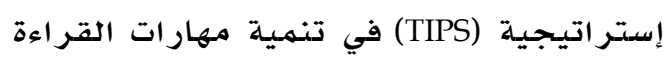

التحليل: عملية يتهم فيها تقسيم الــص إلـى

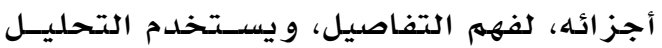

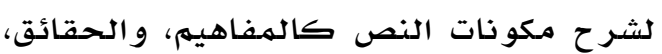
والأحداث، أو البيانات.

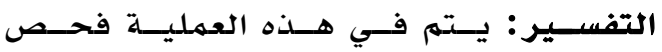
العلاقات بين أجزاء النص، والنص كلير لكل. التركيب: العمليـة التـي يـتم مــن خلالهـا

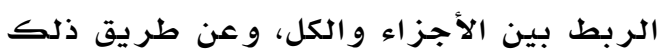

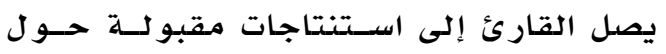
العلاقات، و تضميناتها. التقويه: و في هذه العملية يتوقع من القارئ

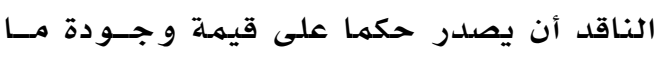

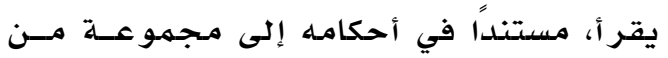
المعايير و لقد حلددت العديد مــن الدراسـات مهـارات

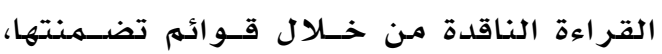

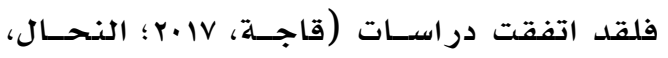

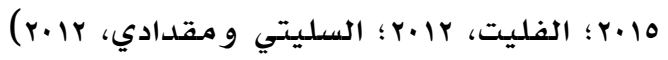

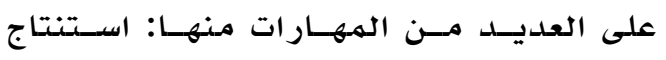
الأسباب الكامنسـة وراء الأحسداث فــي الهــادة

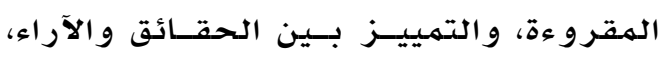

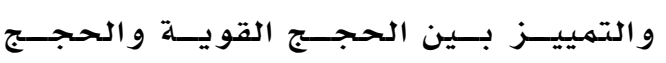

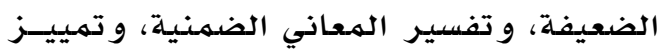

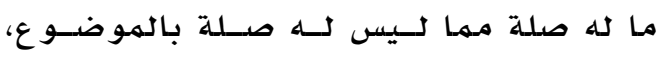
و استنتاج هدف الكاتب، واستخلاص النتــائج،

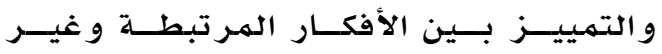

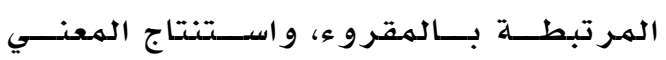

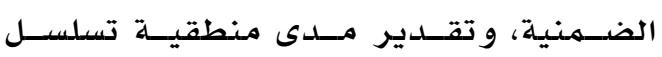

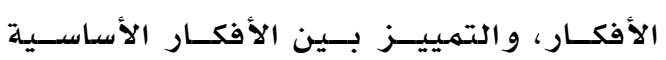

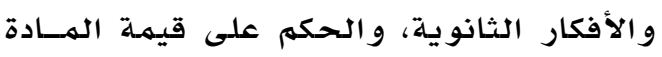

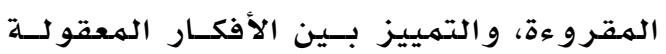
وغير المعقو للة.

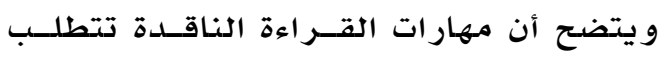

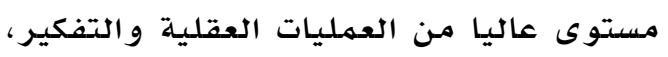

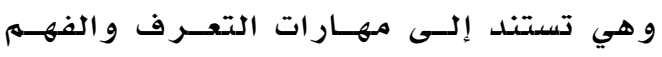
كأساس لها، إذ أن الفهم يعتبر ركنًا أساسيًا

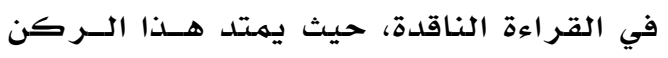
من المعنى المباشر حتى يصل إلـى مسـتوى النقد و التقو يهم. 
وهــذا مــا أكدتــه نتــائج دراســـة الســليتي

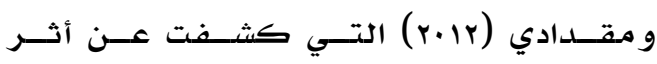

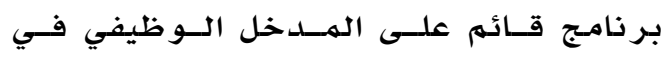

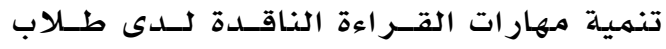

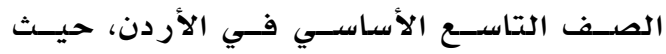

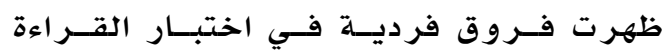

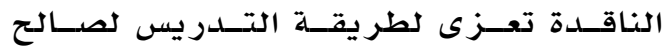

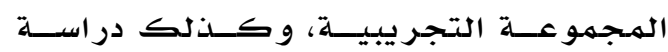

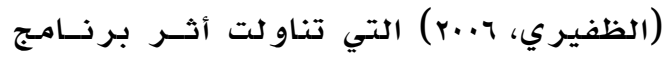

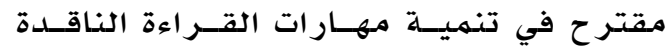
لدى عينة من طلبـة كلية التربيسة بجامعسة مهرة

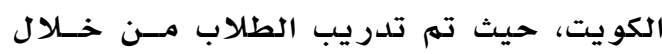

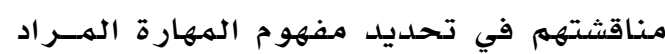

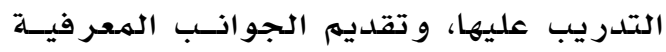

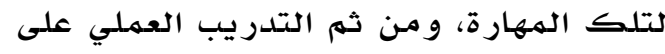

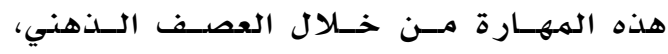

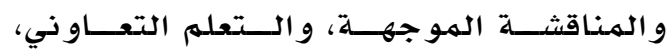

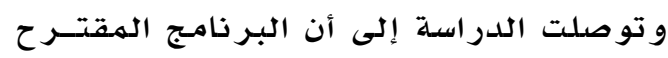

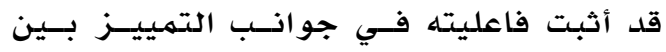

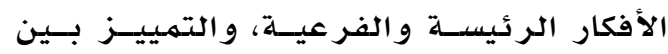

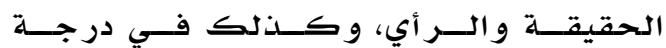

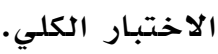

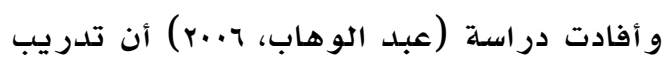

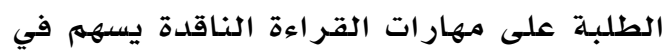

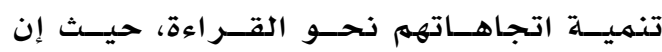
البرنامـج التعليمي المقدم للطلبـة بما تضمنهل

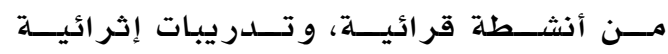

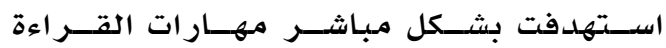
الناقدة، كان له أثر واضح في تحسن اتجــاه أفر اد المجموعة التجر يبية نحو القراءة. ومن الوسـائل الفاعلــة فـي تنميـة مهــارات

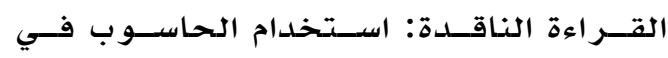

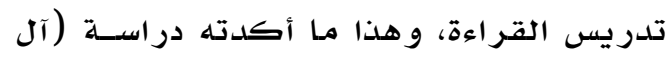

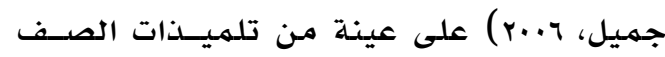

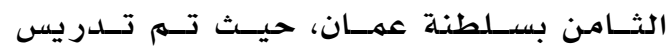

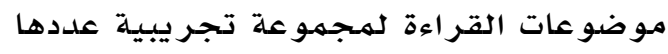

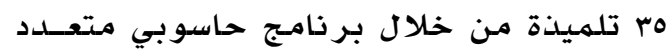

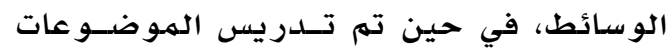

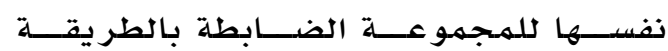

الناقـدة حيـث أظهـر ت النتــائج ان خطــوات

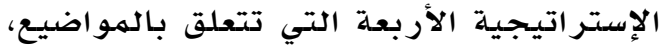

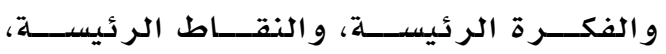
و الملذخص، كان لها أثر كبيـر فـي تعلـيم

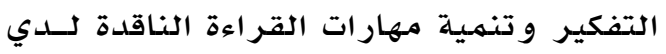
طلبة الصف الخامس.

و ويسهم تدريب الطلبة على التســاؤل الــذاتي في تحسـين القــراءة الناقــدة لــدى طالبــات الصف الخامس، حيث أكسـدت نتـائج دراســة

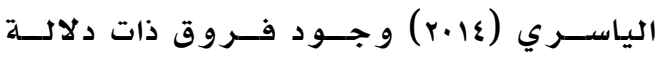

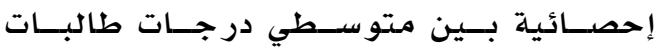

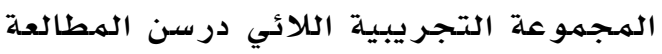

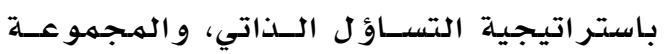

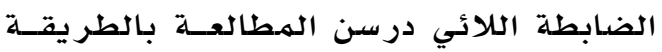

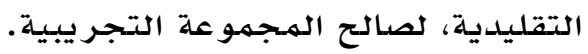
و أشـارت دراسـة النحــال (10 r) إلــى فاعليـة تو ظيـف اسـتر اتيجيتي النمـذجسة و التســاؤل الذاتي في تنميلة مهارات القراءة الناقدة لدى لدى

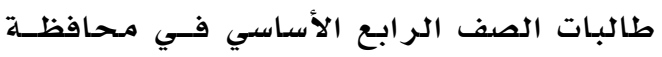

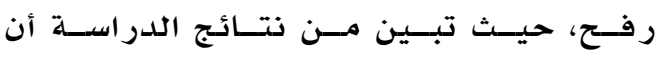

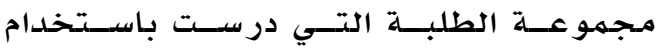

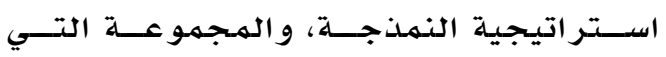

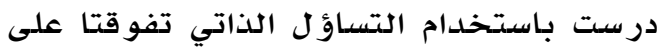
المجمبوعة الضـابطة التي درسـت بالطريقـة الاعتيادية. - الاهجو.

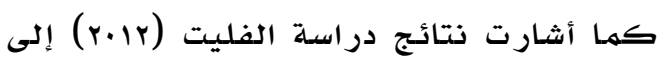
أهميـة استخدام أسئلة في مستويات عليا مــن الفهم، لهما تتطلبـه من قدرات تفكيرية ناقـديدة تتمثل في تصميهم نشاطات وتـدرريبات، تتـيح

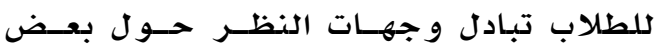

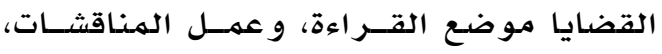

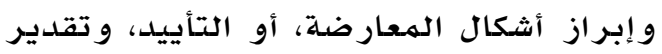

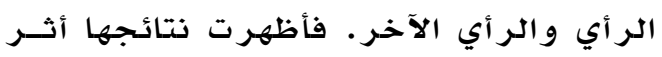
توظيف الأسئلة التقويمية في تنمية مهار التحرن القر اءة الناقدة كــى طلبــة الصــف العـاشـر

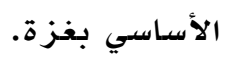

و من العوامل التي تساعد في تنمية مهـارات القراءة النـاقدة: تحقيق قدر مــن الوظيفيـة و التكاملية في تناول مهارات القر اءة الناقدة، 
ذهنية، بحيث يستطيع من خلالهـا أن يسدمـج

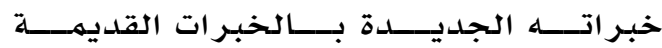

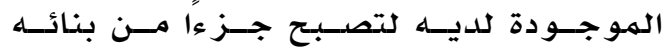

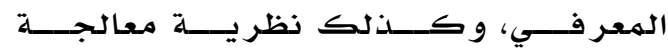

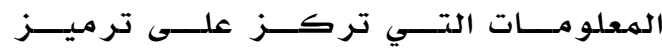

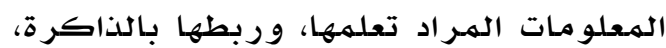

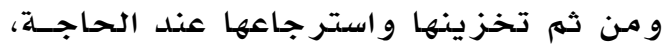

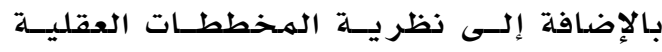
التي تساعد على إعطاء العاله و الأثياء قيمـة

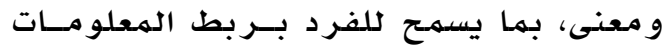
بعضها البعض وتحو يلها إلى حزم ذات معنى بحيث تشغل حيزا أقل ذاكرة، مها يسمـح لها معالجة عمليات معرفية أكثر وبالتالي تعلم

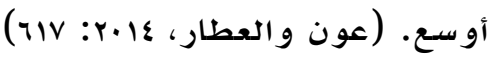

و تتضـح أهمية استراتيجية التصـور الـذهني في كو نها من استر اتيجيات التخــزين التـي تتم في شكل صدور ذهنيـة، حيث تعسد نظـائر

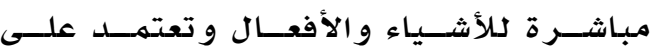
الخصائص الحسية الإدراكية لهذه الأشــياء، الهاء و تفيد في زيادة معنى المعلومات من خـلالول

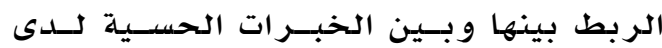
الفر د. (العقيلي، rا.r. ror) و يرى بعـض البـاحثين أن التصـور الـذهني

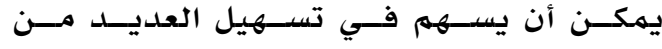
الوظائف مثل: تخزين المعلومات مات باـــاكرة

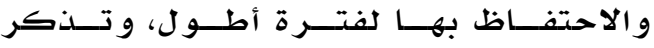

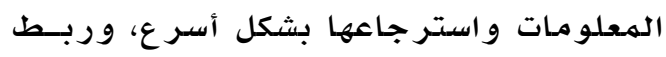

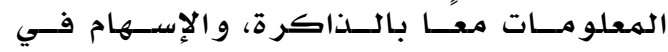

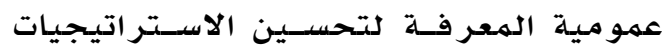

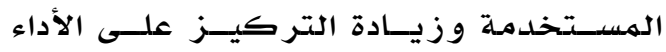

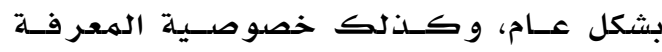

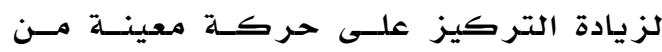

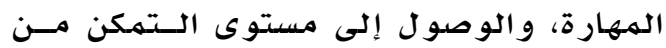

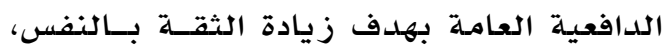
والاحتفــاظ باتجـــاه إيـجـــابي نحســو الأداء،

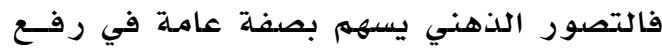

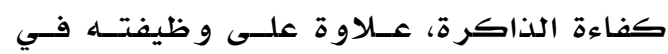

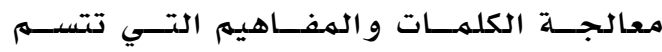

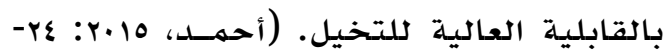

التقليديــة، و أســفر ت النتـــائج عـن تفــوق تلميذات المـجمورعة التجريبية، حيث تحسـن

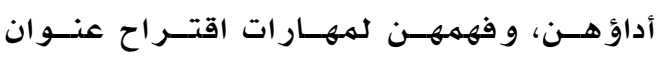
مناسب للنص المقروء، والتمييز بين الأفكار

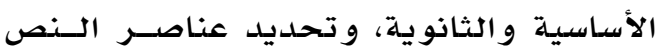

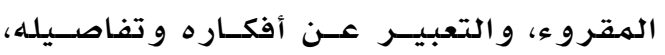
كما زاد من قدرتهن على توقع النتائج مسن وفئن

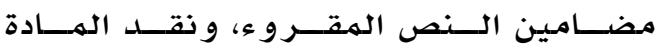
المقرو وة، و إبداء الر أي فيها.

و تعد استر اتيجية التصور الذهني أداة فاعلـة

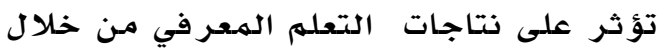
النشاط الذهني، والعمليات العقلية التي يقوم

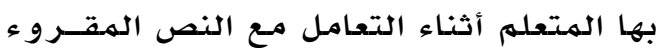

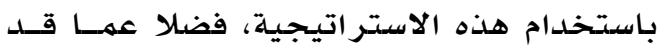
تسهم بـه من دور في تحقيق التفاعل الصفي و المشار كة الإيجابية.

ويشير التصور الذهني إلى القدرة على ربط

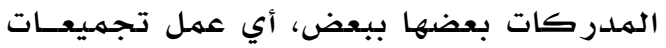
منها علـى هيئسـة صـور عقليسة تلتقـي مــع الخبرة السـابقة للفرد، وهو يشير إلى شـكل هيتل

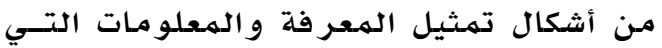

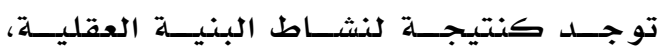
واستحضضار الأشياء فـي الــذهن علـى هيئسـة صور في غيبـة مصادررها الحسية، أي تمثيـل

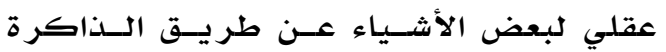
والتخيل، كما يشير إلى عملية شبـه حسـيـية

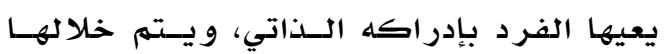
إعادة تركيب أو تشـكيل الخبــرات الحسـيـية مـن المعلو مـات المـخزنة فــي الـذاكرة حـــال غياب هذه المددركات في الواقع و التي يهكن

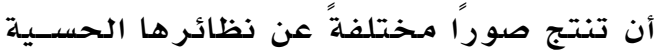

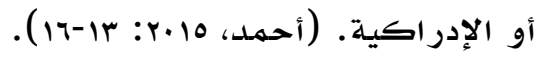

و يرى البعض أن استراتيجية التصور الذهني

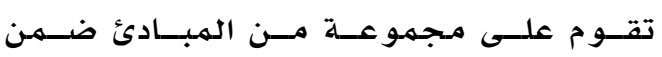

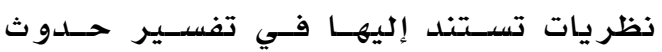

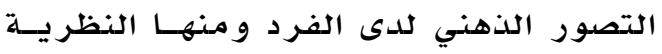
المعرفية، و نظرية التمثيـل المعرفي فـي التــي يحول فيها المتعلهم ما هو موجود في في العالم

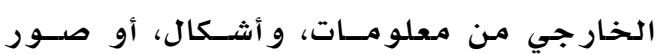


الذهني، و وتعرف فاعلية ذ ذلك في فهم الهقروء والتفكير الإبلداعي لدى ولى طالبات

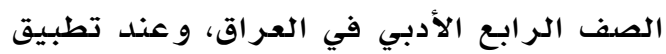

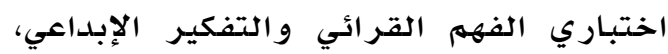

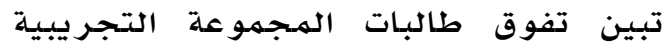
التي درست مـادة المطالعـة باستعمال التصور الذهني، على طالبات المجمو عة الضابطة التي درست المادة نفسها بالطريقة التقليدية في فهم الهقروء و التفكير الإبداعي.

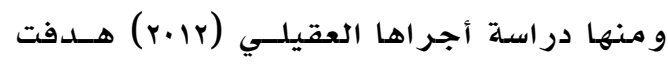
إلى تعرف فاعلية بر نامـج تدريبي قائم علـى

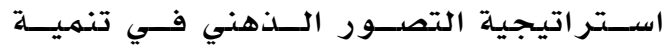

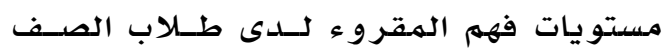
السـادس الابتدائي، حيث تم تحلديـد مهــارات

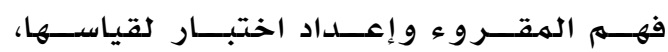

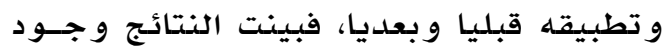
فروق ذات دلادـة إحصسائية بـين متوسيــي

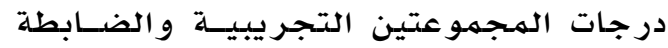
في مهار ات مستويات الفهم لصالح التجريبية

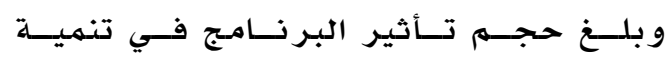

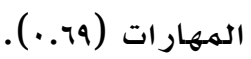

وفي ذات السيـاق أكدت دراسـة عبــد البـاري

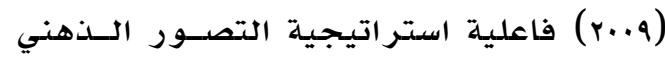

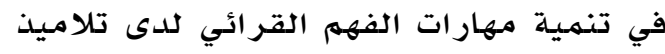

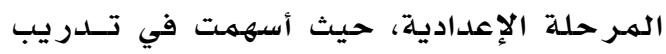

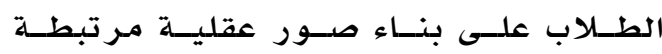

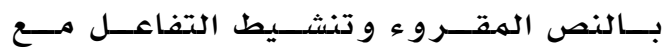
المـحتوى القر ائي.

و فـي ضــوء مــا ســبق يمكــن الإفــادة مسـن

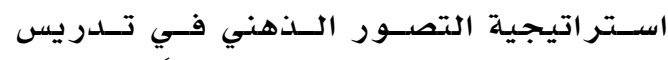

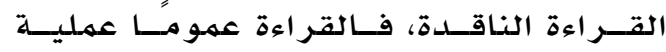
تصور و بناء للمعنى، و مهما يسلدعم ذلـك مهـا تشير إليه دراسـات علمية بينت أن الفهم هـو ودهاء حسن تصور المعنى وجودة اسـتعداد الــذهن، فعند قراءة الطالب أية كلمهة قر اءة سـليمسة

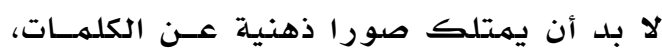
بحيث ترتسهم في عدة صور منهــا: الصــورة

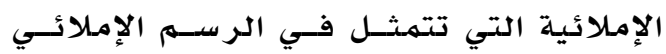

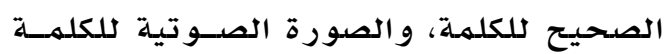

وفسي ضـوء ذلــك يشـكل التصـور الــذهني معينات للذاكرة عبر مجمهوعة مسـن الصـور

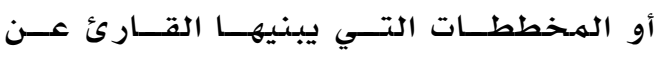
الموضوع المقروء، وهذه الصور ربهو ربما تبـدو

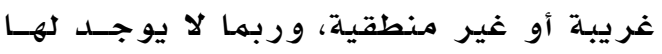

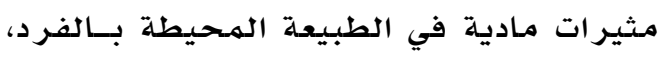

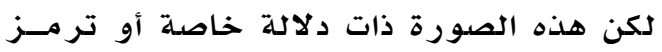

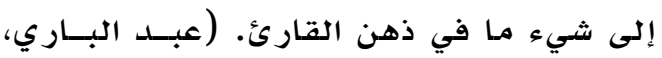

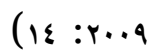

و تسـاعد عملية الترابط المعرفـي للخبـرات الجديدة في تيسير اكتسابها، بشـكل يسـهم

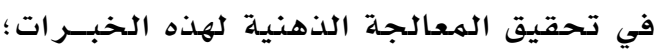

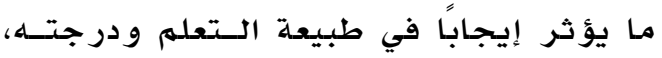
و العمل على تطوير التفكير الناقد.

ولقد حظيت اسـتر اتيجية التصدور الــذهني

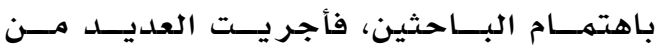

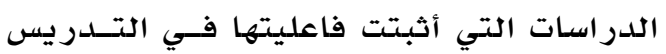

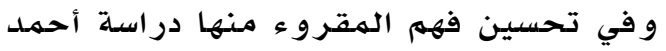

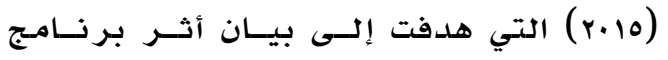
قائم على التصور العقلـي فــي تحســين أداء الذاكرة العاملة والفهم القر ائي لدى تلاميذ الديذ

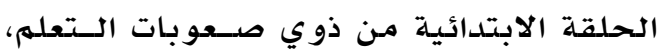

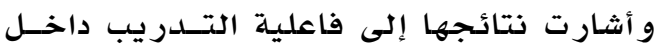

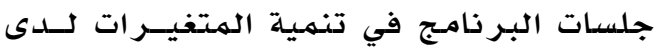

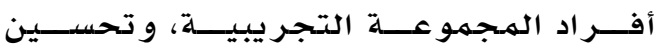

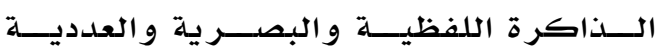
و مهار ات الفهم القر ائي لديهم.

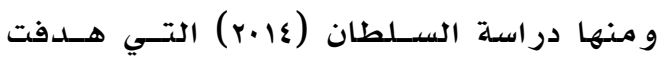
إلى تعرف أثر طريقة تسلدريس قائمسـة علـى

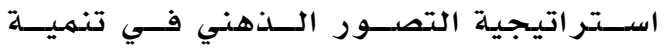

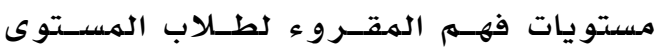
المتقدم من متعلمي اللغة العربية بلغة لغة ثانية،

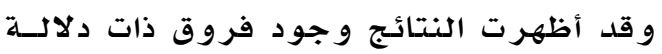

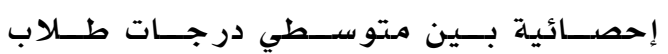

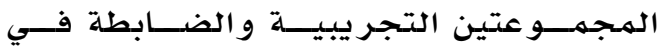

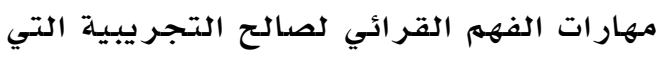
درست باستخدام التصور الذهني.

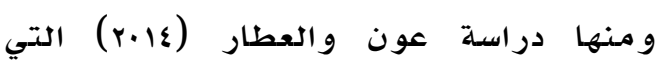
عمدت إلى تدريس الهطالعة باعتماد التصور 
ما أثر استخدام استراتيجية التصور الذهني في تنمية مهارات القراءة الناقدة للى طلاب

الصف التاسع بغزة ؟

و يتفرع من هذا التســاؤل الأســـلة الفرعيـة

التتادية:

1. مـا مهارات القراءة الناقدة المناسبة

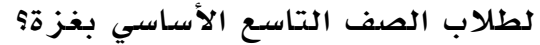

r. هل توجد فروق ذات دلالة إحصدائية

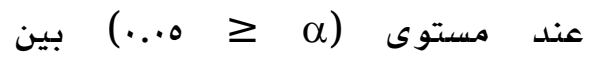

متوسطي المجمهوعتين

التجريبية والضـابطة في التطبيق

البعدي لاختبار القراءة الناقدة ككل

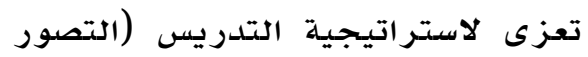

الذهني- الاعتيادية)؛

r. هل توجد فروق ذات دلالة إحصائية

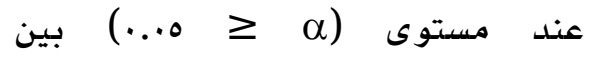

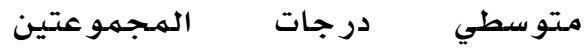

التجريبية و الضابطة في كل مهارة

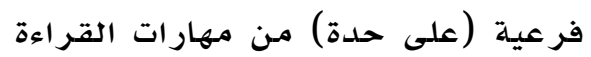

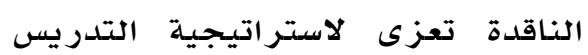

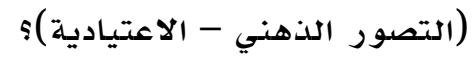

أهداف الدراسة - - اس

يمكن تلخيص أبرز اهداف هذه الدراسـة فيهـا يلي:

تحديد مهار ات القراءة الناقدة

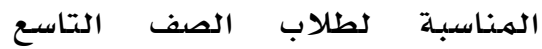
الأساسدي.

التعرف إلى مستوى طلاب الصف

التاسـع في مهار ات القر اءة الناقدة.

بيان أثر توظيف استراتيجية

التصور الذهني في تنهية مهارات القر اءة الناقدة.

الإسهام في تحسين تعليم القراءة

الناقدة وتنهمية مهار اتها لدى طلاب

الصف التاسع الأسـاسي.
التي تشير إلى الطريقة التي يتهم من خلالها نطق أصوات الكلـمـة، والصورة الدلاليـة التــي تشير إلى معنى الكلهــة، والصــورة الحسـيـية

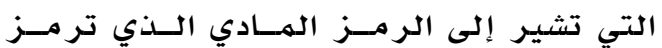

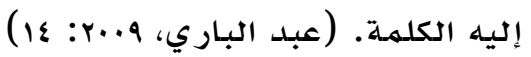

و على صعيد المهتمهـع الفلســيني، فإنــه لا يكاد يخفى عن أعين الهطّلعين على المستوى

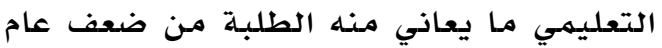

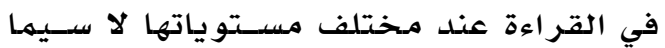
مستوى القراءة النـاقــدة. وهـــا مــا أكدتـهـ

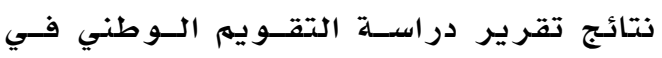

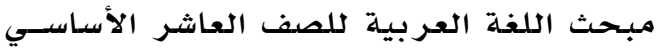
التي أظهـرت انخفـاض مسـتوى التحصـيل

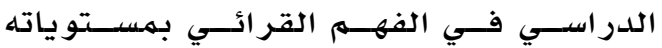

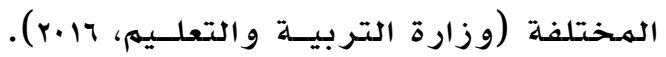
و هذا يدعو إلى مزيد من الاهتمام بـالقر اءة

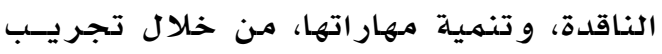

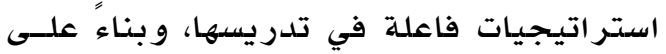
ما سبقى فإن الدراسـة الحالية تحظى بأهميتها

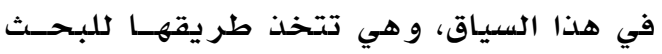
في تعرف أثر استراتيجية التصسور الــذهني

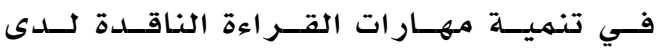
الطلبـة؛ إسهامـا في مسـاعدتهم على اســتخدام الأسلوب العلهي، والتفكير النـاقـد، و وتأكيــل

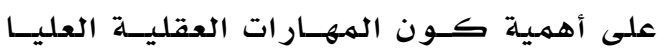
مححور المناهج الدراسية. تحديد مشكلة الدراسة تتحسدد مشـكلة الدر اســة فـي ضـعف طــلاب الصف التاسـع في مهـارات القــر اءة النـاقــدة، و افتقار هم لاستر اتيجيات فاعلــة تسـهم فــي تنهيتها لديهم، خاصدة ونحن نعيث في عصر يستلزم تنـمية هذه الههارات. و للتصدي لهذئه

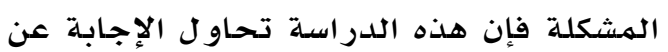
السؤال الرئيس التالي: 
الهقرو ء، و تفاعلهم مـع مهحتوى هـذا الـنص، وتتضهـن هذه الإجر اءات بناء مسجمو عـة مـن

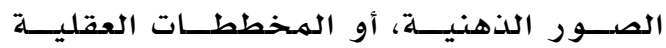
المعينة على استخلاص المعساني المتضـهنة في النص الهقروء.

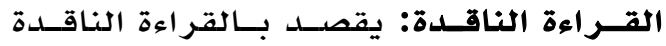

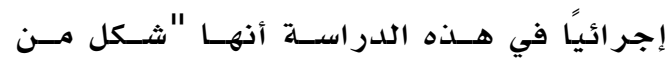
أشكال القر اءة و إحدى مستوياتها التي تتهثل فـي الاســتيعاب المتعـمــق لمهـتـوى الــنـ الهقــروء، مسن خـالال التفاعـل مسـع المــادة المقروءة تفاعلا يهارس فيه القارئ التحليل و التفسير والتر كيب والتقويم بها يسهم في تنهيـة القدرات العقلية العليا".

مهارات القــراءة النـاقــدة: يقصـد بههــارات القراءة النـاقدة فـي الدراســة الحـاليـة أنهـا مظاهر الأداء اللغوي الذي يـتم فـي سـرعة ودقة و يهكن مهلاحظتـهـ وقياسـه مسن خـلال استجابـات الطابــ حــول البنــود الاختبـاربـة الهـرتبطة بالقراءة الناقدة. و تقاس بالدرجة الكلية المتححصلة على اختبـار صـادق وثابـت أعد لهذه الغاية.

\section{أهمية اللدراسة}

تتهـل أهميـة الدراسـة في عدة ذقاط هي: ا. يتوقع لهذه الدراسلة أن تفيـلـ و اضــي الهناهـج الدراسية وذلك بهـا تسهم به مـن توجيـــ اهتمهـامهم إلـى مســتوى القراءة النـاقدة، ووما يتطلبـه هذا النوع مـن القر اءة مـن مـر اعــاة عنــد تطـوير

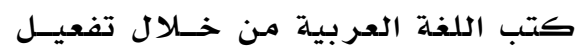

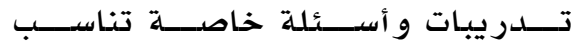
الهستوى الناقد

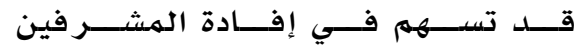
التربـوبين و ذلــك عنــد عقــد دور ات

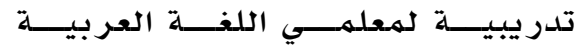
و معلمهاتهـــا مــن أجــل لفــت أنظــار

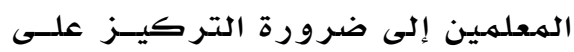

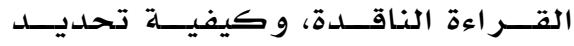
مهار اتها و أسـاليب تنهـيتها و استهدافها.
فروض الدراسة

ا. توجد فروق ذات دلالهة إحصائية عند

مستوى (.

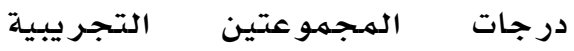

و الضدابطة في التطبيق البعدي لاختبـار

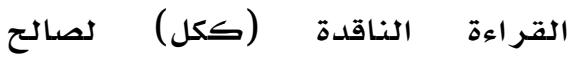

المهجمو عة التحجر يبيـة.

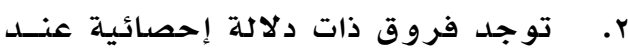

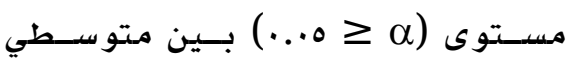

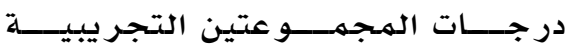
و الضدابطة في كل مهارة فر عيـة (على حسـدة) مــن مهــارات القتـر اءة النـاقـدة لصدالح المهجمو عة التتجر يبيـة. r. توجد فروق ذات دلالة إحصـائية عنــد

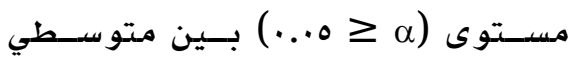

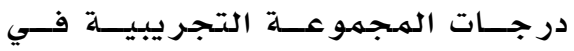
التطبيقين القبلـي و البعسـدي لاختبــار

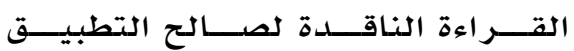

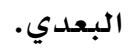

حلدود الدراسة

تقتصر هذه الدراسلة على الحدوود التالية:

عينــة مــن طـلاب الصــف التاســع الأسـاسي، في مدرسـة عبـد الكـريهم العكلـورك الأسـاســية العليــا التابعـة التهية لمديرية تعليم الوسطى.

مهارات القــر اءة النـاقـدة المنـاسـبـة لطلاب الصف التاسع عمــا تتحـدد في ضوء آراء المشر فين التربــويين و المعلمين. الفصل اللدراسـي الثــاني مــن العـام

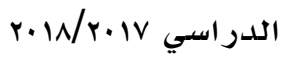

مصطلهات الدراسة

استراتيجية اتتصسور اتـذهني: يقصسـ بهـا إجرائيا في هذه الدراسلة أنها مهجموعـة مــن الأنشطة والإجــر اءات العقليـة التـي يتبعهـا طلاب الصف التاسع عند تعاملهم مـع الـنـ 
الرجوع إلى الأدب التربوي المتمثل

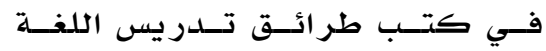

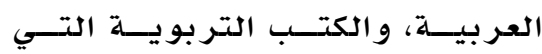
تناو لت تعليهم القراءة.

الاطلاع على دراسات و بحوث سـابقة

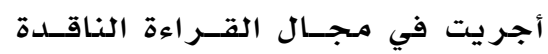
و عنيت بتحديد مهار اتها وتنـميتهـا.،

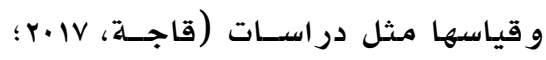

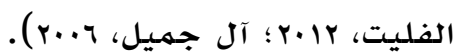
عرض قائمهة الههارات على مجموعة من المحكمين ضمهت أساتذة جامعات، و متتخصصسين فـي طر ائسق تــدر يس

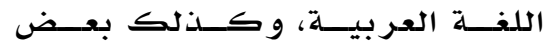

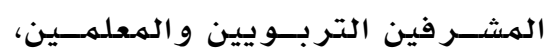
و طلب منههم إبداء الــر أي فـي مـــى التى

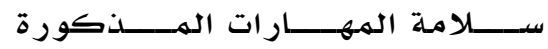
كمهار ات للقر اءة الناقدة، وبيان مـا إذا كان هناك مهارات أخرى يمكسن

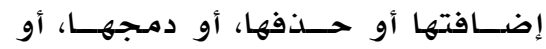

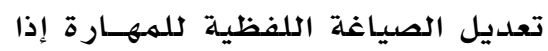
تطلب الأمر ذلك.

عرض القائمسة على عينـة مكونة مــن 10 فردا من المشـر فين التربـويـين،

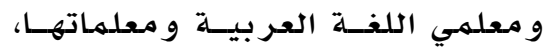
لمعرفة آرائهم في أهمية المهـهارات

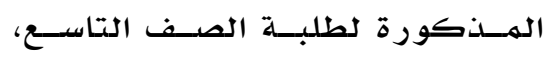
حيث تم اختيار المهار ات التي حصلت

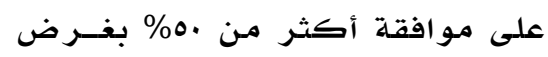

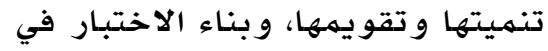

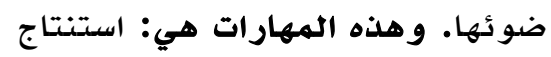

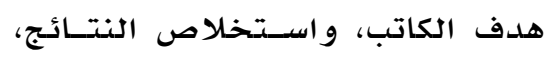

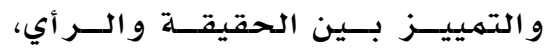

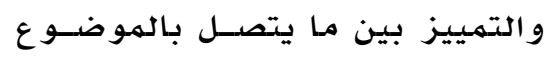

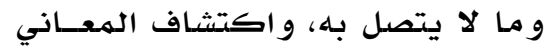

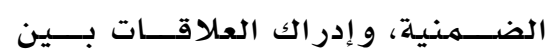
الأفكار، والتمييز بين الحجـج القوية الهرية و الحجج الضـعيفة، و إصــدار أحكـام

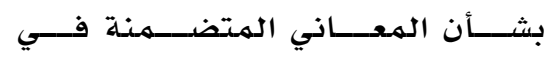

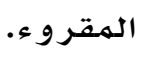

r. قد تساعد الهعلمين: وذلك من خلال

تزو يدهم بتصور لتوظيف استر اتيجية

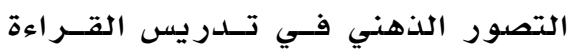

الناقدة.

؟. ع -- قد تفتح هذه الدراسة المجسال أمام

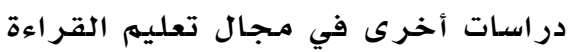

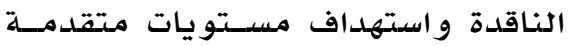

من التفاعل مـع الهمادة المقروءة

\section{إجراءات ومنهجية الدراسة}

اعتمـدت الدراسلة على استخدام المـنهج ثــبـه التجريبي، لمعر فة أثر استر اتيجية التصدئ التهور

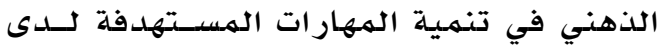

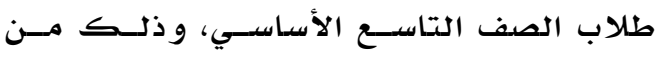
خلال اختيار مجمموعتين: مجمموعة تجريبية

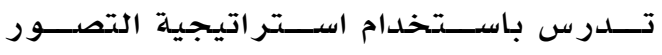

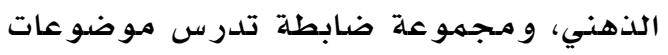

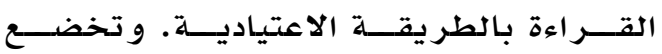
المجرمو عتان لتطبيقين قبلي و بعدي لاختبـار مهار ات القراءة الناقدة.

عينة الدراسة تكونت عينة الدر اسـة من به طالبًا مـن طـلاب مدرسة عبد الكريم العكلوك الأسـاسية العليـا، و هي مدرسـة للذكور تابعة لوزارة التربيسة

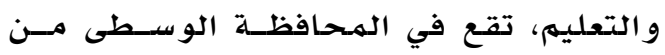
محافظات غزة بفلسطين، وذلك في الفصسل ولكل

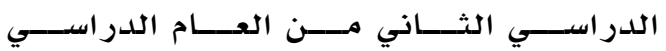

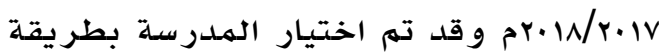
قصدية؛ مـراعاة لتسهيلات إجر اءات التطبيـق، حيث تم اختيـار فصـلين عشـوائيا مسن بــين

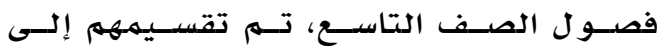
مجمهـو عتين: تجر يبيــة و عــددها اء طالبــا، و ضابطة و عددها •ـ طالبـا.

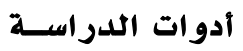
اعتمددت الدراسـة على استخدام اختبـار لقياس

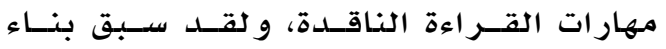

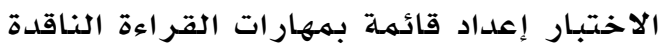

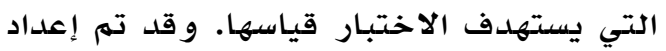
هذه القائمهة من خلال الإجر اءات التالية: 
7. من أسباب انتشار المخدررات في

المـجتمـع

V . تماسك الأمة و المجتمـع دليل على.

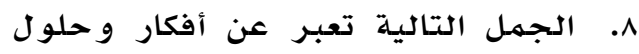

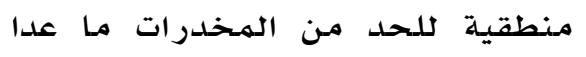

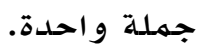

9. الهدف الذي يسعى الكاتب إلى تحقيقه. •l. يستنتج من الفقرة الثانية.

11. الجمل الآتية تعبّر عن آراء ماء عداء جملة واحدة تعبّر عن حقيقة. rا. في العبارات الآتية عبارة لا علاقة لها

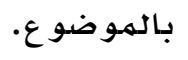
سا. يُفههم ضهمنياً من الهـوضدوع. عا. الأسباب التي تجعل الشباب صالحاً للقيادة.

10. العبارة التي تمثّل أقوى الحجج على و جوب بذل الجهد لإتقان الأعمال.

17. أعتقد أنّ السبب الذي دفع الكاتب لهذا

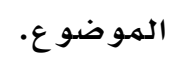

IV. الهدف من إعداد الشباب العربيّ

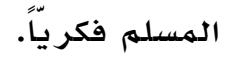

11. على الشباب ألا يفرضوا لأنفسهم

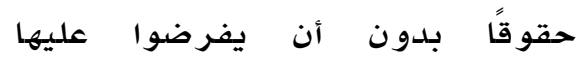

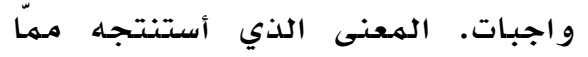

سبق.

19. فيما يلي ثلاث حقائق ورأي واحد هو. •r. من خلال اطِلاعك على النص حلدّد أيّ

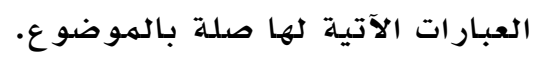

اץ. الفكرة التي لا تتفق مـع رأي الكاتب

هي. ك. السبب الرئيس لإعداد الشبـاب العربيّ المسلهم فكر يـاً.
صياغة مفردات الاختبار

اعتمــدت الدراســة الحاليــة علــى الأســـئلة

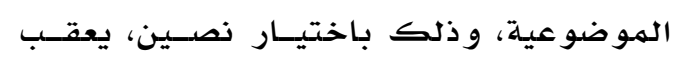

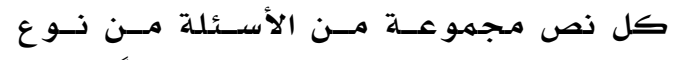

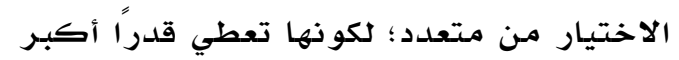

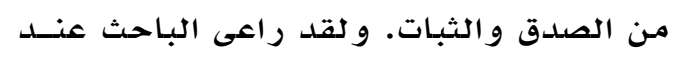

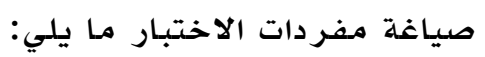

1. أن تكون نصوص القــراءة المتضـمنـة

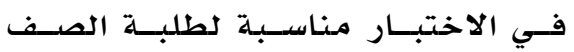

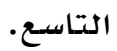

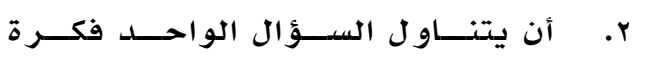
محددة.

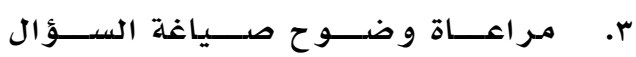

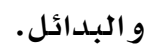

ع. أن تغطـي الأســـلة جميــع المهـارات

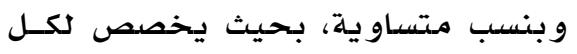
مهارة ثلاثة أسئلة. ه. التوازن بين البدائل من حيث الطــول و التر كيب اللغوي.

7. توزيع الإجابة الصحيحة بطريقة غير منتظمة لتقليل فرص صد التخمين. وقد تكون الاختبار مـ عن فقرة اختبارية

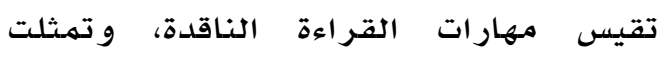
مقدمة فقر ات الاختبار فيما يلي: ا. يهدف الكاتب في الفقرة السابقة إلى إبر از.

r. زيادة الإنتاج في المـجتمـع تترتب على عوامل كثيرة منها.

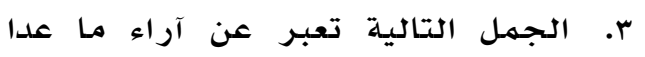
جملة و احدة تعبر عن حقيقة.

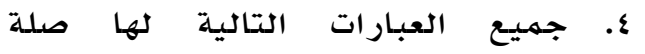
بالهـوضدوع السابق مـع عدا واحدة.

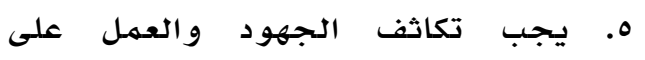

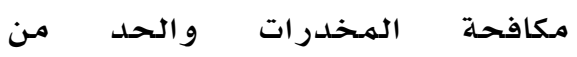
انتشار ها، و السبب في ذلك. 


\section{تحديد الزمن الكلازم للاختبار}

تم تحديد الزمن الكلازم للإجابة عن أسئلة

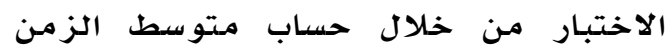
الذي استغرقه أفراد المجموعة باستخدام

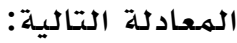

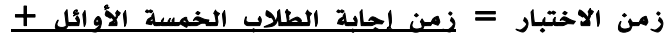
زمن لجابة الطلاب الخمسة الأواخر 1.

$0 .+00+0 .+0 .+\varepsilon 0+9 .+00+0 .+\varepsilon 0+\varepsilon$. 1.

وقد تبين أن الزمن اللازم دلاختبار هو .ال دقيقة

الصورة النهائية للاختبار

في ضوء الخطوات السابقة، أصبح الاختبار

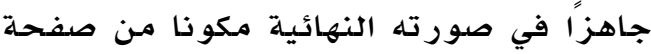
الغلاف، وصفحة خاصة بالتعليمات، و اشتمل على نصين، يعقبهما مجموعة من الأسئلة

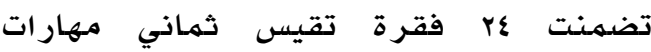
للقراءة الناقدة، بواقع ثلاث فقرات للوات للمهارة الواحدة، وجدو ل ايوضح ذلك.

\section{تصحيح الاختبار}

عند وضع معيار التصحيح، تم توزيع درجات

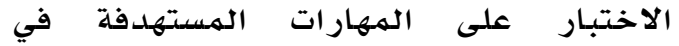

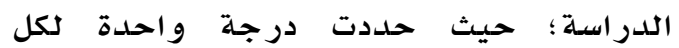

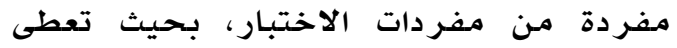
الإجابة الصحيحة علامة و واحدة، والإجابة الخطأ صفرا، وبذلك تكون الدرجة الكلية للاختبار أربعا و عشرين درجة، حيث يتكون الاختبار من أربع وعشرين مفردة جميعها وناريا من نوع الاختيار من متعدد. وبذلك ونك تكون مفردي الدرجة القصوى كلاختبار \&广، و تكون الدرجية

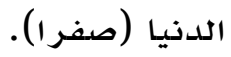

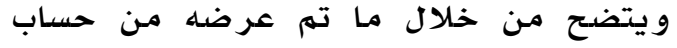
صدق الاختبار وثباته، أن الاختبار يتسمى بدرجة مناسبة من الصدق و الثبات، وتعليماته واضحة، و مفر داته مناسبة؛ ممما يجعله صالحا للتطبيق على عينة البحث قبليا و وبعديا، لمعرفة فاعلية استراتيجية التصور الذهني في تنمية مهار ات القراءة الناقدة.

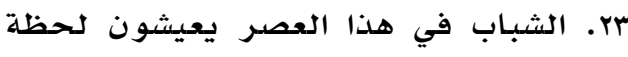
عالمية، حدد أقوى الحجج التي تدل على ذلك ممًا يلي. گr. الشباب الذين يشعرون بأنّهم لبنة في بناء الجماعة التي ينتمون إليها. يكونون حريصين على. صدق الاختبار (Test Validity): و للتأكد من صدق الاختبار، وصلاحيته لقياس المهارات المستهدفة، تم قياس الصدق

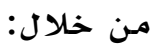

صدق المحكمين: وقد تحقق هذا

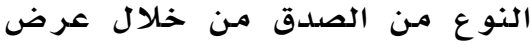

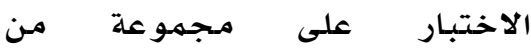
المحكمين المتخصصين في مجال المال المناهج وطر ائق تلدريس اللغينة

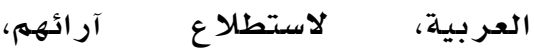

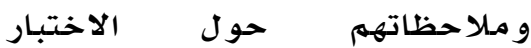

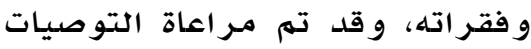
التي أجمع عليها المحكمون.

Internal الاتساق الداخلي (Consistency Validity) إيجاد الاتساق الداخلي للاختبار بعد تطبيقه على عينة استطلاعية قوامها

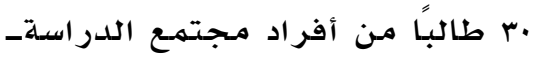

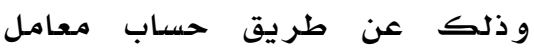
الارتباط بين كل فقرة من فقرات

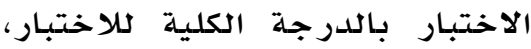
وذلك لتعرف قوة معامل الارتباط الناتج، حيث تراوحت قيم معاملات

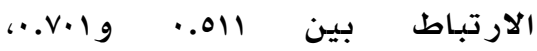

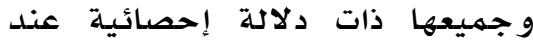

$$
\text { مستوى 1.... }
$$

ثبات الاختبار (Test Reliability):

تم حساب معامل ثبات الاختبار من خلال

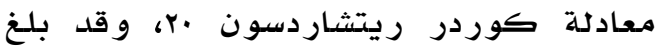

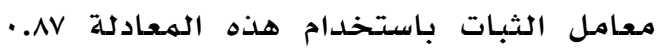

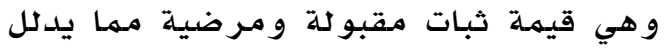
على ثبات الاختبار و صلاحيته للاستخدام. 
مفردات الاختبار التي تقيس مهارات القراعة الناقدة المستهدفة

\begin{tabular}{|c|c|c|}
\hline الدفردات التي تقيسها & المهارات & ? \\
\hline 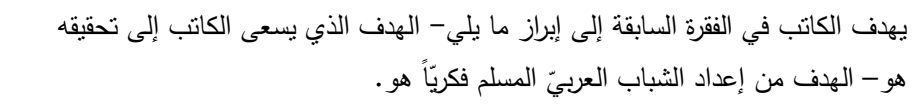 & استتاج هدف الكاتب & 1 \\
\hline 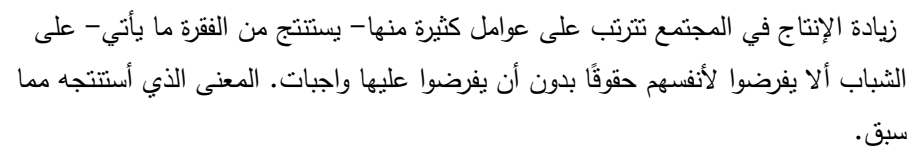 & استخلاص النتائج & r \\
\hline 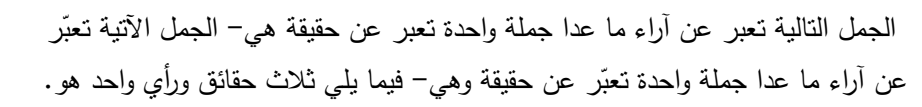 & التمييز بين الحقيقة والرأي & r \\
\hline بالمها بالموضوع، وهيع - من خلارات التالية لها صلة بالموضلاعك على النابق مع عدا- في العبّ العبارات الآتية عبارة لا علاقة & والتمييز بين ما يتصل بالموضوع لا يتصل به & $\varepsilon$ \\
\hline يجب تكنياً من الموضوع الجهود والعمل على مكافحة المخدرات والحد من انتشارها، وذلك لأن - يُفهج & اكتثاف المعاني الضمنية & 。 \\
\hline السبب الرئيس لإعداد الثباب العربيّ المسلم فكريّاً. & إدراك العلاقات بين الأفكار & 7 \\
\hline 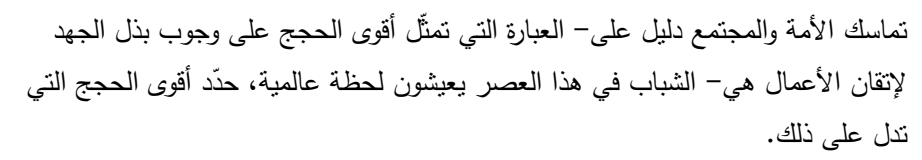 & الضتمييز بين الحجج القوية والحجج & $\mathrm{v}$ \\
\hline 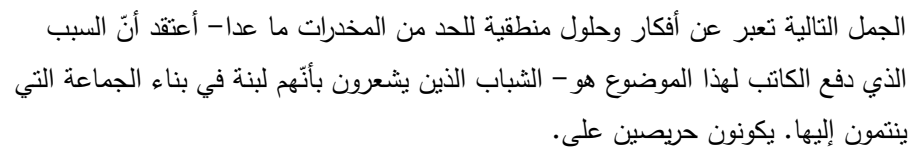 & إلصدار أحكام بشأن المعاني & $\wedge$ \\
\hline
\end{tabular}

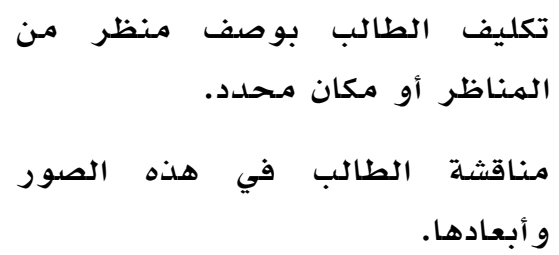

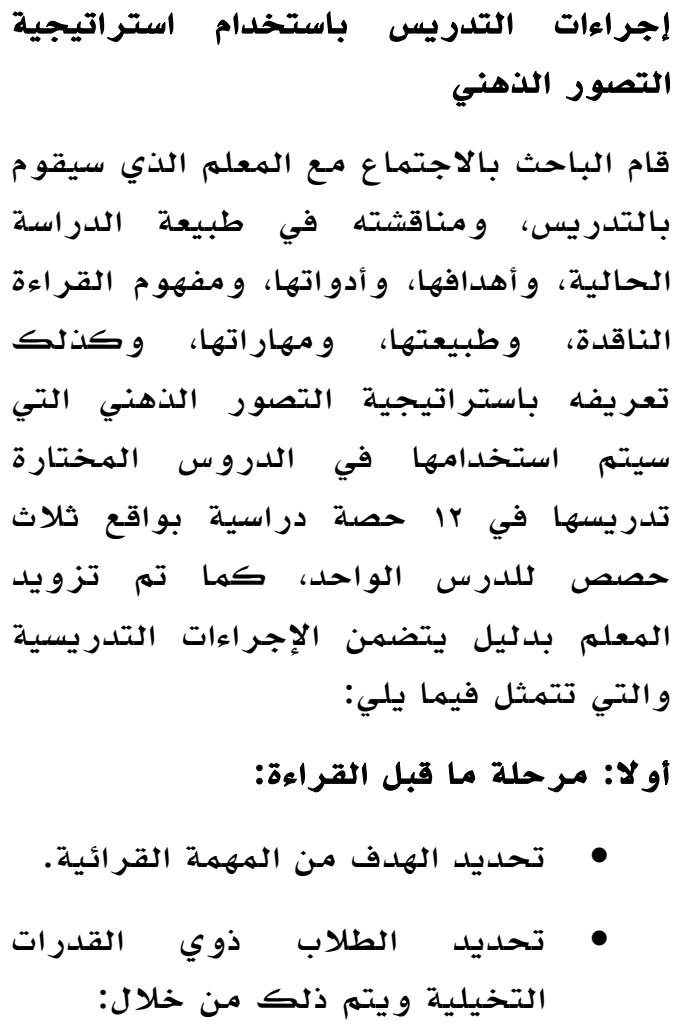


مـا الصورة التي يريد الكاتب أن تصل للقارئ؟ انصورن ما العلاقة بين الأفكار الفرعية

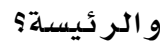

ما الصورة التي يمكن رسمها رهمها للشخصية الرئيسة كلموروض اهو مر اعاة مناقشة مجمموعة الصور التي تم تكوينها في أثناء القر اءة. مرراعاة منح كل طادب الوقت الكافي للقراءة وسعى كل منهم في تكوين الصور كمعينات للذاكرة. قر اءة الموضوع قر اءة صامتة. متابعة القراءة الصامتة للطالب و تدو ين المعلو مـات الأسـاسية.

تكليف الموضوع و مححاولة تذكر أية فكرة أو حدث يرتبط بالموضوض. مطالبة الطالب الإجابة عن بعض الأسئلة المطرو حلة.

التقويه: للتأكد من تحقيق أهداف اللدرس وله و وسائل متعددة منها

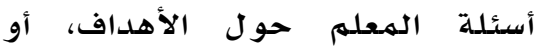
أسئلة الطلبة بعضهم لبعض، أو أو أونها

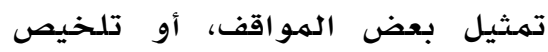

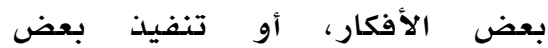
الأنشطة الهنتميلة.

رابعا - تكليف الطلبة بالأنشطة الإضافية والتعيينات البيتية.

\section{نتائج الدراسة}

النتائج المتعلقة بالسؤال الأول:

كان نص السؤال الأول هو: مـا مهارات القراءة الناقدة المناسبـة لطلاب الصف التاسع بغزة بهز

و لإججابة عن هذا السؤال، تم تحديد مهارات

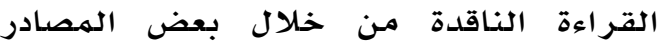

نمـذجة الهعلم أمام الطلاب لكيفية

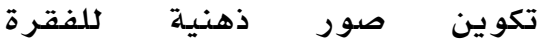
المقروءة.

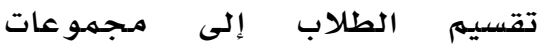
تعاونية صغيرة، ثم يتم توزيع

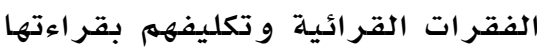
قراءة صامتة وتكوين ورسهم صورة عقلية مـرتبطة بالفقرة.

يقوم الطلاب برسه الصورة العقلية التي ارتسمت في ذهنـه عن الفقرة. تبادل هذه الصدور مـع الأقران،

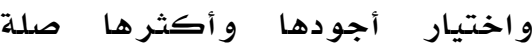

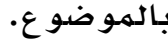

يعرض المعلم أفضل هذه الصور على الطلاب.

إجراء مناقشة بين الطلاب من جهة وبين الطلاب والهعلهم من جهة ثانية عن تفضيلهم لصورة ذهنية دون

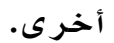

تكليف كل مجمموعة بشرح وتفسير

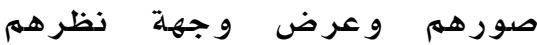
تجـاهها.

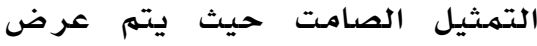
بعض الصور، أو تمثيل أداء شخصية،

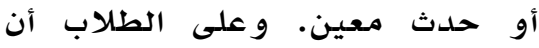
يحددوا هذا الححدث.

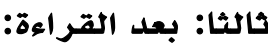
طرح مجموعة من الأسئلة التي تدور حول

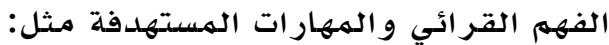
ما الفكرة العامة للهموضوع؟ • ما أبرز المشاهد في هذا الموضوع؟ ما الأماكن التي وردت في النص؟

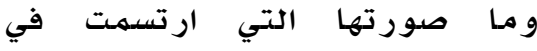
ذهنك؟ 


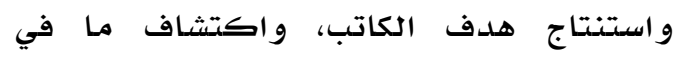
النص المقروء من تناقضات. النتائج المتعلقة بالسؤال الثاني: كان نص السؤال الثاني هو: هل توجد فروق

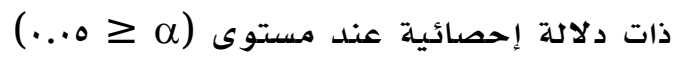
بين متوسطي درجات المجمو عتين التجريبية و الضابطة في اختبار القراءة الناقدة ككل

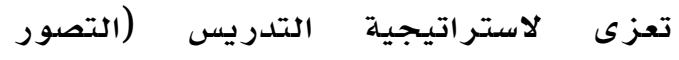
الذهني- الاعتيادية)؟ تعزي

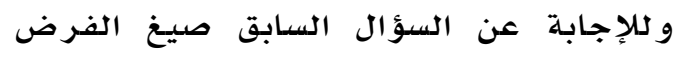
التالي: لا توجد فروق ذات دلالة إحصائية

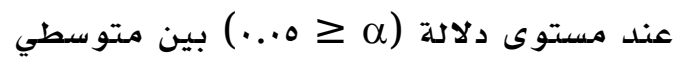

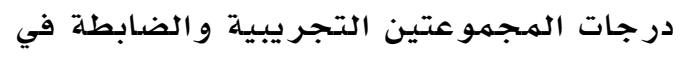

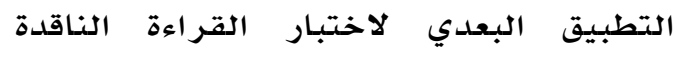

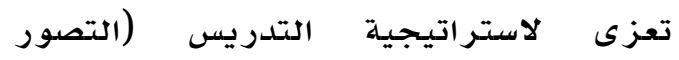
الذهني - الاعتيادية).

و للتحقق مـن صدحة هذا الفرض تم استخراج

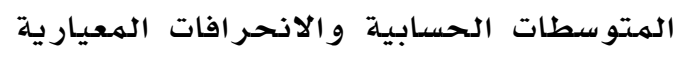

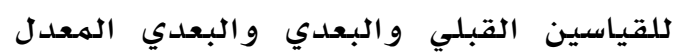

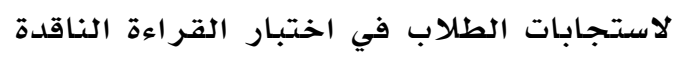

$$
\text { ككل، و جدو ل r يبين ذلك: }
$$

يبين جدول r و وجـود فـروق ظاهريــة بـين

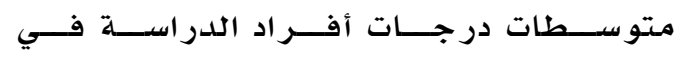

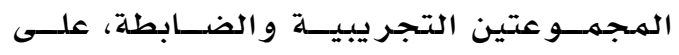

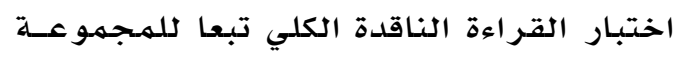

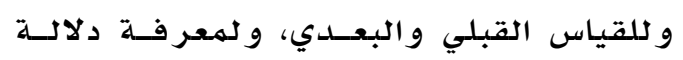
هذه الفروق تم إجراء اختبار تحليل التغـاير

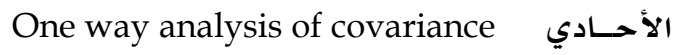
وجدو ل r يبين هذا التحليل. (Ancova)
منها: كتب طرائق تدريس اللغة العربية، و البـحوث و الدراسـات السابقة التي أجريت في

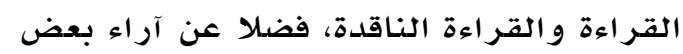

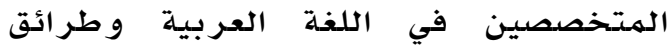
تدر يسها.

وقد تم عرض هذه المهارات على عينة مكونة من 10 فردا من المشرفين التربوين همدهين

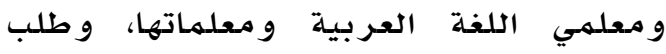

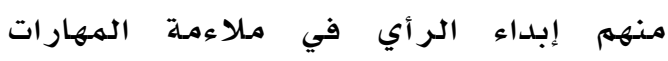

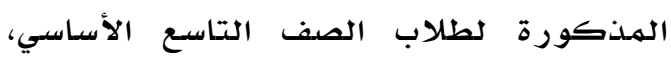
حيث تم اختيار المهارات التي حظيت بنسبـة

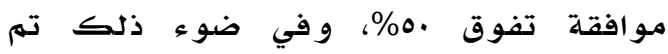

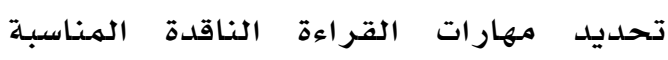
لطلاب الصف التاسع، وتمثلت فيما يلي: القدرة على نقد الهقروء وإصدار الأحكام بشأنه، و تقدير منطقية تسلسل الأفكار في

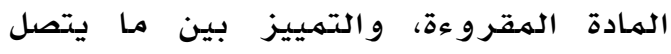

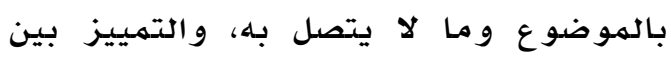
الحقائق والآراء المطرو وحلة، والتمييز بين والهين الحقيقة والخيال، والقدرة على الربط بين والهين

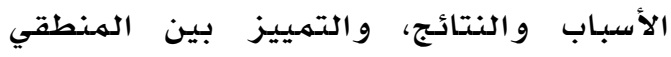

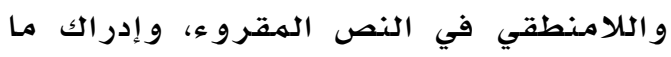
يتضمنه الهقروء مـن و هم و مغالطات، و إبداء الرأي فيما اشتهمل عليه المقروء مـن أفكار

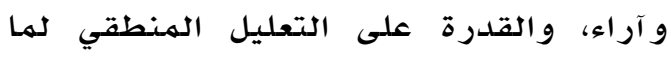

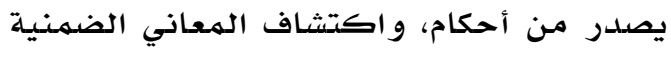

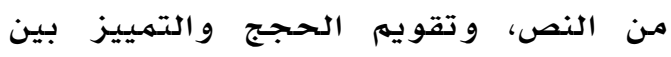

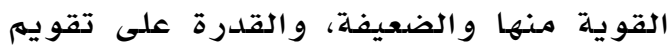

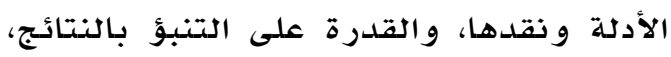

\section{جدول r}

المتوسطات الحسابية والانحرافات المعيارية للقياسين القبلي والبعدي، والبعدي المعدل لاستجابات الطلاب في اختبار القراءة الناقدة ككل

\begin{tabular}{|c|c|c|c|c|c|c|}
\hline \multicolumn{2}{|c|}{ البعدي المعدل } & \multicolumn{2}{|r|}{ البعدي } & \multicolumn{2}{|r|}{ القبلي } & \multirow{2}{*}{ المجموعة } \\
\hline الخطأ المعياري & المتوسط الحسابي & الانحر اف المعياري & المتوسط الحسابي & الانحر اف المعياري & المتوسط الحسابي & \\
\hline.$\wedge 7 \varepsilon$ & Ir...9 & 0.71 & Ir... & 0.747 & $1 \cdot . r \ldots$ & الضابطة \\
\hline . Aor & $17 . V \leqslant V$ & $0 . T_{1}$ & 17.907 & ๆ. . & $1 \cdot . \leqslant r q$ & التجريبية \\
\hline .107 & $1 \leqslant . r V$ & 0.90 & $1 \varepsilon . \varepsilon \cdot V$ & $0 . \vee \wedge 0$ & $1 \cdot . r V$ & 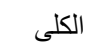 \\
\hline
\end{tabular}




\section{جدول r}

نتائج تحليل التغاير الأحادي للقياس البعدي لاختبار القراءة الناقدة بين المجموعتين التجريبية والضابطة

\begin{tabular}{|c|c|c|c|c|c|c|}
\hline 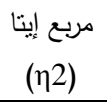 & الدلالة الإحصائية & ق قيمة ف & متوسط المربعات & درجات الحرية & مجموع المربعات & مصدر التباين \\
\hline \multirow{4}{*}{.0174} &.$r 10$ & $1.07 \pi$ & $\sum 7.77$ & 1 & $\leqslant 7.77$ & القياس القبلي (المشترك) \\
\hline & $\cdots$ & $10 . r 19$ & $\leq 0 \leq . \varepsilon$ & 1 & $\leq 0 \leq . \varepsilon$ & طريقة التدريس \\
\hline & & & r9.101 & vA & rTrA.q & الخطأ \\
\hline & & & & 1) & $197 \leq V$ & الكلي \\
\hline
\end{tabular}

(على حدة) من مهار ات القر اءة الناقدة تعزى (لهـ

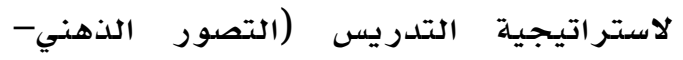

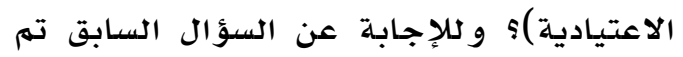

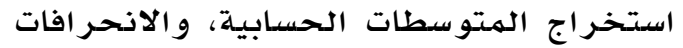

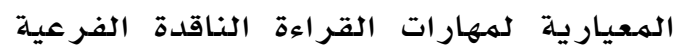
بين أفراد الهجهموعة التجريبية والضـابطة

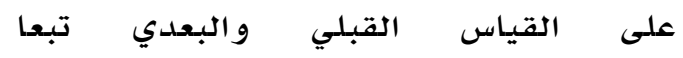

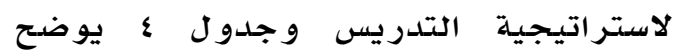
ذلك.

يبين جلدول ع وجود فروق ظاهرية في المتوسطات الحسـابية والانحر افات الهمعيارية

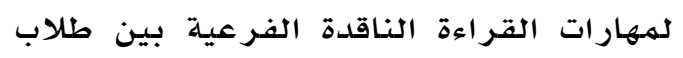

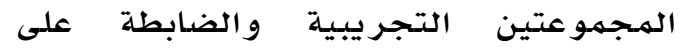

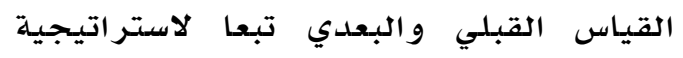

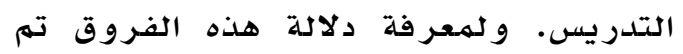

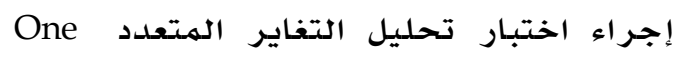
way multivariate analysis of covariance و جدو ل ه يبين هذا التحليل. (Mancova)
يبين جلدول r أن قيمهة "ف" للدرجسة الكليـة

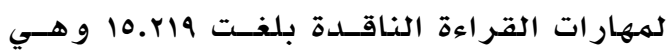

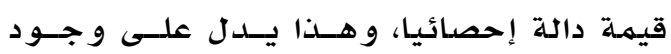
فـروق ذات دلالــة إحصــائية عنــــ مســتوى

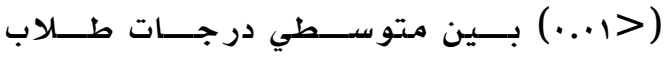

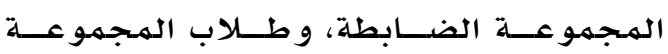
التجريبية في اختبار القراءة الناقدة البعسدي

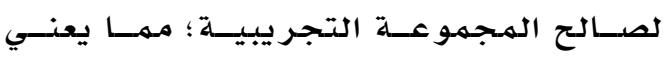

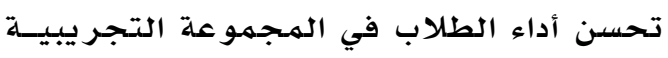

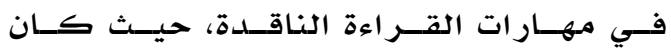
المتوسط البعدي المعدل لدرجات الطلاب في

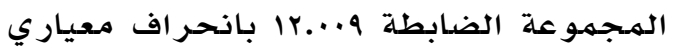
ع 1..، بينما كان متوسط درجات الطلاب في

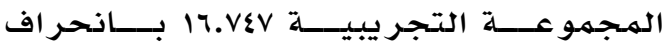

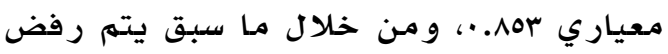
الفر ض الصفري، وقبول الفرض البديل الذي يظهر وجود فروق ذات دلادلة إحصـائية بـين

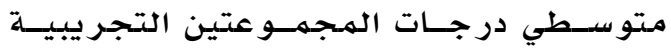

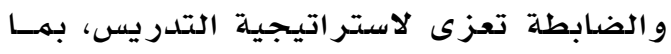

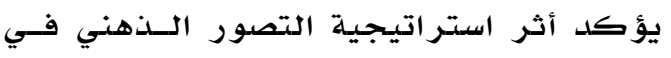
تنهية مهار ات القراءة الناقدة، و إســهامها فـي تحسين مستوى الطلاب فيها، وهذا يشير إلى أن ما تضمنته إستراتيجية التصـور الــذهني من إجراءات قد ساعد الطلاب على بناء صور

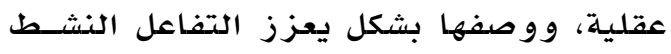

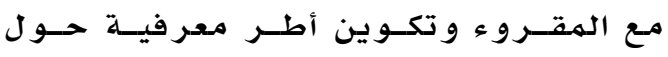
مضامينه. النتائج المتعلقة بالسؤال الثالث: كان نص السؤال الثالث هو: هل توجل الثل

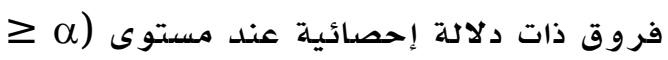

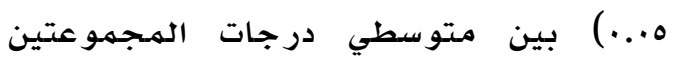
التجريبية والضابطة في كل مهارة فرعية 


\section{جدول}

المتوسطات الحسابية والانحرافات المعيارية لمهارات القراعة الناقدة الفرعية لاى طلاب المجموعتين التجريبية والضابطة على القياس القبلي والبعدي تبعاً لاستراتيجية التدريس

\begin{tabular}{|c|c|c|c|c|c|c|c|}
\hline \multicolumn{2}{|c|}{ البعدي المعدل } & \multicolumn{2}{|c|}{ البعدي } & \multicolumn{2}{|c|}{ القبلي } & \multirow{3}{*}{ المجموعة } & \multirow{3}{*}{ ال الأبعاد } \\
\hline الخطأ & المتوسط & الانحراف & المتوسط & الانحراف & المنوسط & & \\
\hline المعياري & الحسابي & المعياري & الحسابي & المعياري & الحسابي & & \\
\hline 4זו & $1.7 \cdot V$ & $1 . . r V$ & 1.040 & I. rov & 1.7 & الضابطة & \\
\hline oro & 1.979 & .94 & r... $\Sigma \wedge \wedge$ & 1.174 & 1.071 & التجريبية & استتناج هدف الكاتب \\
\hline .1 ro & $1 . \mathrm{VAN}$ & $1 \ldots 1$ & 1.29 .1 & 1.41 & 1.01 & 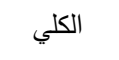 & \\
\hline$. r V \leq$ & $1 . r 0$ & .917 & D D I.ro &.$\wedge \varepsilon$ & l.ro & الضابطة & \\
\hline.$r Y I$ & T.rד & r.IVA & r.rq.r & $.9 \leq 9$ & 1 & التجريبية & استخلاص النتائج \\
\hline .rVY & 1.101 & 1.201 & $1 . \wedge T \leqslant r$ &. $.19 \varepsilon$ & $1.1 \mathrm{ro}^{\circ}$ & الكلي & \\
\hline$. .1 \leq 9$ & 1.290 &. .909 & $1 . \leqslant 0$ &.$\wedge M \wedge$ & .940 & الضابطة & \\
\hline$. .1 \leq V$ & $r_{.} \cdot v \wedge$ & $. \wedge \leq r$ & T.ITr & $.94 r$ & $1 . . v r$ & التجريبية & التمييز بين الحقيقة \\
\hline$\because 1 \leq 1$ & $1 . \vee \wedge 7$ & .901 & 1.199 .1 & $\because 91$ &. .999 & الكلي & \\
\hline. $.1 V r$ & 1.210 & .99 .0 & $1 . \leqslant V_{0}$ & $1 . .11$ & $1 . .0$ & الضابطة & التمييز بين ما يتصل \\
\hline$. .1 V \mid$ & r...TE & 1.191 & r..VRr & $1 . . r r$ & 1.181 & التجريبية & بالموضوع وما لا \\
\hline.$I V Y$ & $1 . V V \varepsilon$ & 1.990 & l.VVVA & $1 . .1 \mathrm{~V}$ & 1.11 & الكلي & يتصل به \\
\hline .017 & 1.711 & .900 & 1.7 & 1.110 & 1.00 & الضابطة & \\
\hline. .101 & r.110 & $\because .91$ & r.1901 &.$\wedge r v$ & $1 . r 41$ & التجريبية & اكتشاف المعاني \\
\hline .0109 & 1.191 & $1 \ldots v$ & $1.9 .1 r$ & .971 & $1 . \varepsilon \cdot 9$ & الكلي & \\
\hline. .194 & $1.0 r r$ & 1.490 & 1.0 & I.r.r & $1 . r$ & الضابطة & \\
\hline. .191 & r.l $\varepsilon$ & l..rr & $r . I V \cdot V$ & 1.170 & $1.2 \wedge \wedge$ & التجريبية & إدراك العلاقات بين \\
\hline $.19 r$ & 1.人ז & $1 . r 09$ & 1.1490 & $1.11 \varepsilon$ & $1 . r 9 \leq$ & الكلي & \\
\hline$\because \wedge \mathrm{AV}$ & 1.095 & 1.519 & 1.040 & $1 . r \cdot 9$ & I.rTo & الضابطة & \\
\hline $.1 \wedge \varepsilon$ & r..00 & $1 \ldots \varepsilon$ & r.ITr & I.KTV & $1.0 \mathrm{rV}$ & التجريبية & لقوية والحجبيز بين الحجج \\
\hline .110 & $1 . \wedge r \leq$ & $1.1 \varepsilon$ & l.NTVY & $1 . r 11$ & $1 . r \wedge 1$ & الكلي & \\
\hline$\because r \cdot V$ & 1.291 & 1.180 & $1 . \leqslant 0$ & 1.1 .0 & $1 . \varepsilon$ & الضابطة & إصدار أحكام بشأن \\
\hline$\because r \cdot \varepsilon$ & $1 . \wedge \cdot 7$ & $1 . T 1 \leq$ & $1.10 \mathrm{rV}$ & 1.010 & $1 . r \varepsilon 1$ & التجربيية & المعاني المتضنمة في \\
\hline.$r .0$ & $1.70 r$ & $1 . r 07$ & $1.70 \leqslant r$ & $1 .+7$ & $1 . r v 1$ & 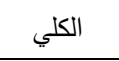 & المقروء. \\
\hline
\end{tabular}


جدول

نتائج تحليل التغاير المتعدد للقياس البعدي لمهارات القراعة الناقدة الفرعية بين المجموعتين التجريبية والضابطة

\begin{tabular}{|c|c|c|c|c|c|c|c|}
\hline مربع إيتا (12) & الإحصائية & قيمة ف & متوسط & الحرية & المجروع & 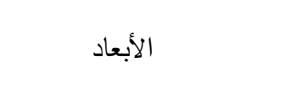 & مصدر \\
\hline $.1 \mathrm{~V}$ & $\cdots v r$ & (1) & T.YVT & 1 & r. rVT & اسنتناج هدف الكاتب & \\
\hline 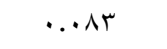 & $\cdot . \cdot r$ & 7.509 & 18.9 .0 & 1 & 18.9 .0 & استخلاص النتائج & \\
\hline .99 & $\cdots 99$ & V.rYA & $0 . \wedge \wedge \varepsilon$ & 1 & $0 . \wedge \wedge \varepsilon$ & التمبيز بين الحقيقة والرأي & \\
\hline$\because 179$ & $\cdots$ ro & $0 . T \leq r$ & 0.1 .9 & 1 & 0.1 .9 & 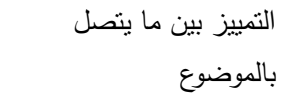 & استراتيجية \\
\hline$\ldots \vee \vee q$ &. .17 & $7 .+7$ & $0 . V Y$ & 1 & $0 . V T$ & اكتثاف المعاني الضمنية & التدريس \\
\hline. $.7 r$ & $. .+1 \leq$ & $\varepsilon .70 \mathrm{~V}$ & $7 . \varepsilon \cdot \wedge$ & 1 & $7 . \varepsilon \cdot \Lambda$ & إدراك العلاقات بين الأفكار & \\
\hline$\cdot .70$ & $\because 9 \leq$ & 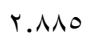 & r.v. 9 & 1 & r.v. & التمبيز بين الحجج & \\
\hline \multirow[t]{17}{*}{$\because 7$} & . & $1 . \cdot \varepsilon$ & $1.7 \leq 7$ & 1 & $1.7 \leq 7$ & إصدار أحكام بشأن المعاني & \\
\hline & & & $.7 \wedge \mathrm{V}$ & $v_{1}$ & E^.VTr & استتناج هدف الكاتب & \\
\hline & & & r.VVT & $v_{1}$ & 197.1 .0 & استخلاص النتائج & \\
\hline & & & $\cdot . \wedge 1 \leq$ & $v_{1}$ & OV.A & التمبيز بين الحقيقة والرأي & \\
\hline & & & $1.1 \cdot 1$ & VI & $\vee \wedge .7 \wedge 1$ & 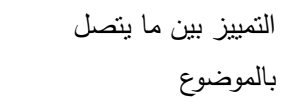 & الخطأ \\
\hline & & & $.9 \leq \varepsilon$ & $v_{1}$ & $78 .+19$ & اكتثاف المعاني الضمنية & \\
\hline & & & I.rvt & $v_{1}$ & 98.790 & إدراك العلاقات بين الأفكار & \\
\hline & & & I.YAT & $v_{1}$ & $91 . r \vee q$ & التمبيز بين الحجج & \\
\hline & & & $1.01 \mathrm{r}$ & $v_{1}$ & $11 T . r \leq 0$ & إصدار أحكام بشأن المعاني & \\
\hline & & & & $\wedge$ & $r \leqslant 1$ & اسنتتاج هدف الكاتب & \\
\hline & & & & $\wedge$ & orv & استخلاص النتائج & \\
\hline & & & & $\wedge 1$ & 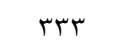 & التمييز بين الحقيقة والرأي & \\
\hline & & & & $\wedge 1$ & ror & التمييز بين ما يتصل & \\
\hline & & & & $\wedge$ & $r v \varepsilon$ & اكنتاف المعاني الضمنية & \\
\hline & & & & $\wedge$ & $\varepsilon \cdot 1$ & إدراك العلاقات بين الأفكار & \\
\hline & & & & $\wedge$ & rVt & التمبيز بين الحجج & \\
\hline & & & & $\wedge$ & $r \leq \Lambda$ & إصدار أحكام بشأن المعاني & \\
\hline
\end{tabular}

جدول الهتوسطات الحسابية يتبين أن الفرق

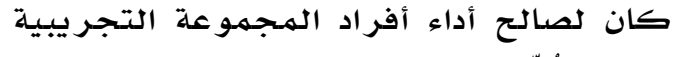

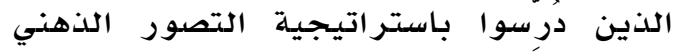

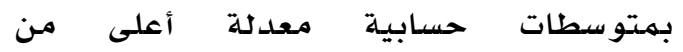

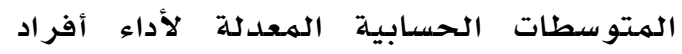

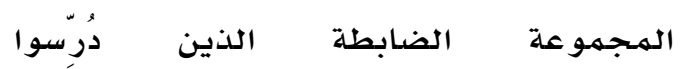
بالاستراتيجية الاعتيادية. كما حسب حجم الضابطم

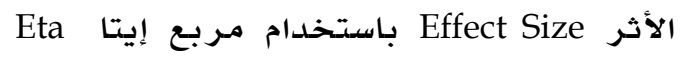

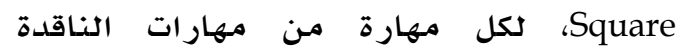

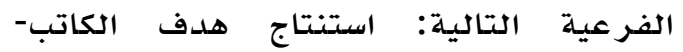

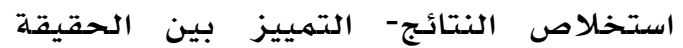

وبالنظر إلى النتائج المبينة في ه السابق

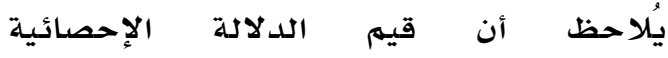

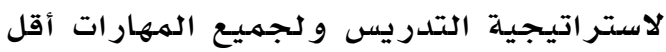

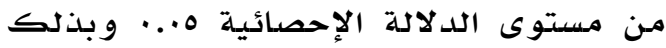

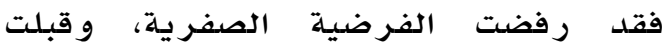
البديلة التي تنص على وجود فروق ذات الفرة

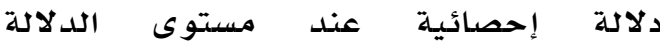
الإحصائية بين المتوسطين الحسابيين لأداء

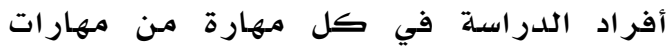

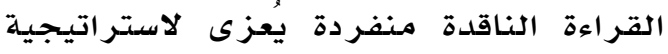
التدريس (التصور الذهني، الاعتيادية). ومن الترة التئية 
ا. استخدام استراتيجية التصور الذهني أتاح للطلاب فرصا مناسبة لتصور

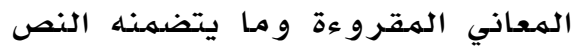

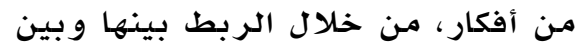

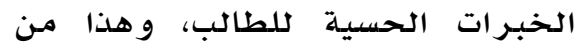
شأنه تنشيط المعر فئة السابقة، وزيادة

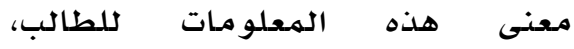

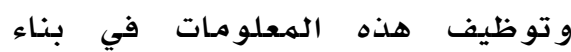
المعر فة الجديدة أو اللاحقة.

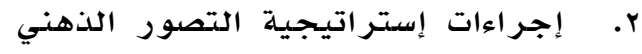

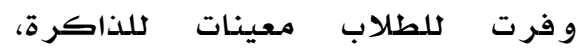
تساعد الطالب في تحديد الكلديد الكمات و المفاهيم و تعرف دلالتها، وهذا يعين في تفسير النص المقروء و وتحليله

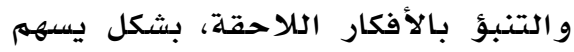
في تدعيم الحصيلة القر ائية و التقدم

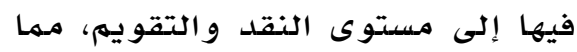

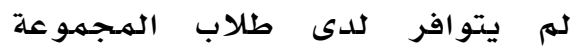
الضابطة، و مـما أسهم في تحسن هذه لهن

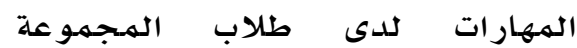

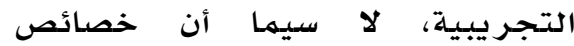

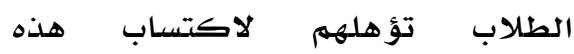
الههارات إذا استهدفت بشكل منظهم. r. تدريب الطلاب على تكوين صور ذهنية على النص راعت مستويات الطلاب حيث يتم من خلال مرلميك مرحلة

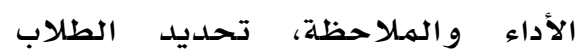

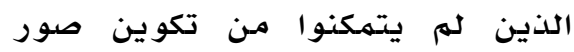

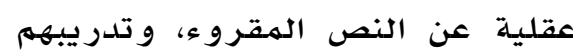

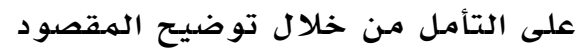

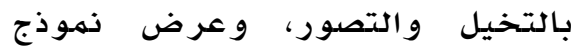
لكيفية تشكيل الصور الذهنية أمام الطلاب وذلك بمحاكاة الهعلم فيما

ع. أسهم توظيف الاستراتيجية في توفير مناخ صفي إيجابي أتاح الفرصدة أمسام

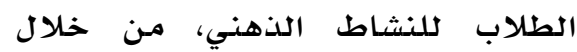

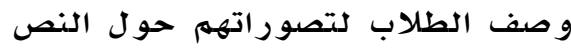

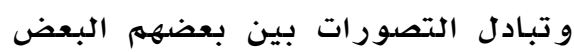

والر أي- التمييز بين ما يتصل بالمـوضوع- الهوان

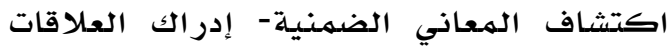

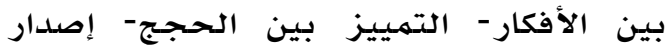
أحكام بشأن المعاني، وبلغت قيمته لههارات

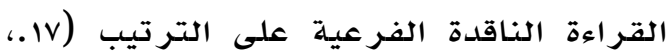

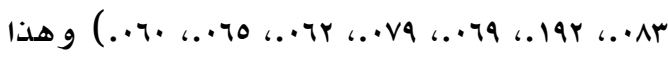
يشير إلى أن تأثير المتغير المستقل المتمثل

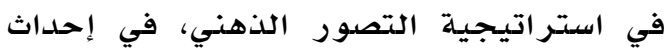
تباين في الهتغير التابع الهتمثثل في مهارات

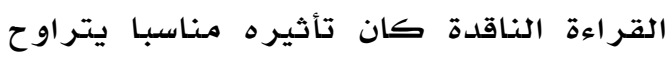
بين الدرجة المتوسطة في بعض الههارات، الهات و يصل إلى درجة كبيرة في مهارات فرعية

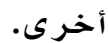

\section{مناقشة النتائج وتفسيرها}

اتضح من خلال النتائج التي سبق عرضها وجود فروق دالة إحصائيا بين متوسطات

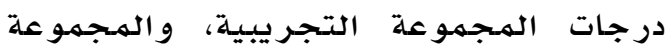

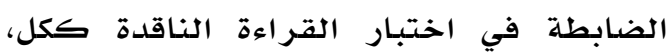
و في جميع الههارات الفر عية للقراءة الناقدة، وقد يعزى ذوفي جلك إلى طبيعة إستراتيجية

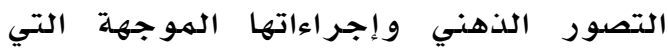

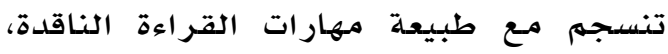

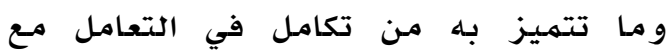
الهحتوى القرائي، فاستراتيجية التصدور الذهني سـاعدت الطالب على بناء العلاقة بين

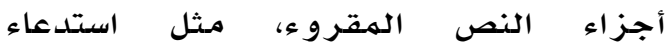
الهعلومـات السـابقة حول محتولى الهن النص، وبناء

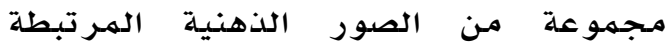
بمحتوى النص، لاكتساب الفهم المتعمق مهن

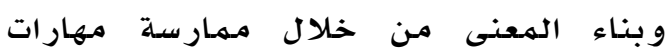
القراءة الناقدة، كهما قد يعزى ذلكى ذلك إلى

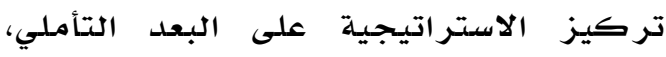

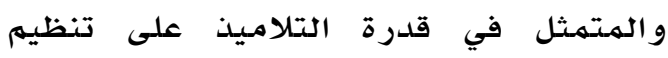

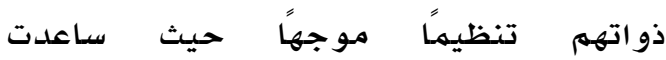

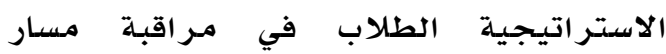

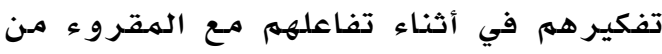

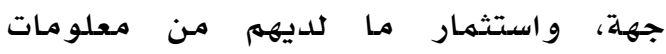
و معارف سابقة من جهة ثانية. و يمكن إيعاز تلك النتائج بشكل محدد إلى النقاط التالية: 
مفهوم الصور الذهنية، وسمات القارئ

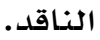

ه. تطوير دليل المعلم في تدريس اللغة

العربية وتضمينه بعض الاستراتيجيات التي تثير التفكير الناقد، والتأملي.

\section{مقترحات لبحوث أخرى}

في ضوء نتائج الدراسة، وتوصياتها، يقترح الباحث إجر اء البحوث و الدر اسات التالية:

1. أثر توظيف استراتيجية التصور

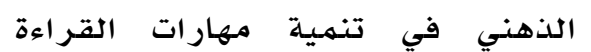

الناقدة للطلاب في صفوف مراحل

در اسية مختلفة المر احل.

r. دراسة أثر استراتيجيات تدريسية

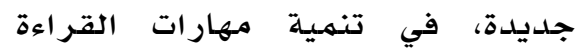

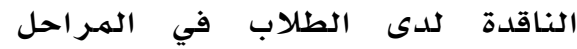

التعليمية المختلفة.

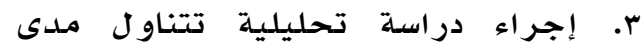
تركيز أسئلة كتب اللغة العرائة العربية للمرحلة الأساسية في فلسطين على الفئل مهار ات القراءة الناقدة.

ع. إعداد بر نامج لتدريب معلمي اللغة

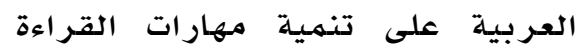
الناقدة لدى طلابهم.

$$
\text { المراجـع }
$$

\section{References}

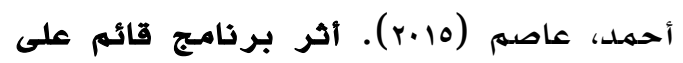
التصور العقلي في تحسين أداء الذاكرة

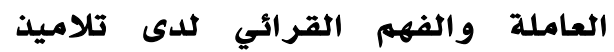

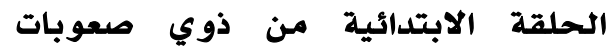
التعلم، رسالة دكتور اه، كلية الدراسات العليا للتربية، جامعة القاهرة.

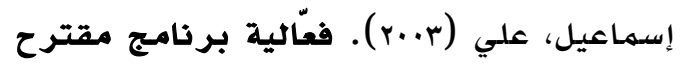

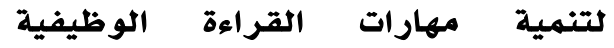

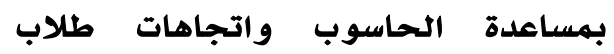
المرحلة الثانوية نحوها، رسالة دكتوراه، غير منشورة، معهد الدراسات التربوية، جامعة القاهرة.
و نوعية الأسئلة الموجهة التي تم

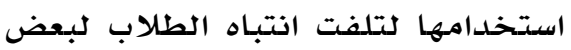

الاحداث و والأفكار تصور ها.

ويتوافق ذلك مـع نتائج بعض الدراسات

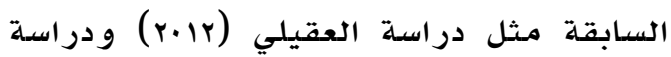

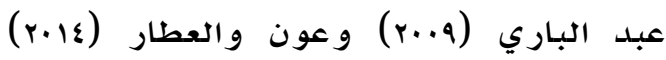

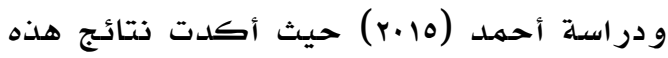

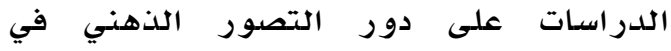

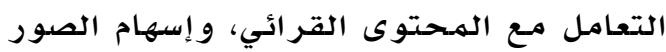

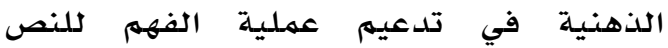

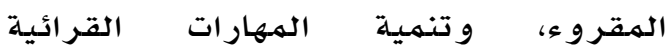
بمستو ياتها المختلفة.

وومن حيث نمو مهارات القراءة الناقدة

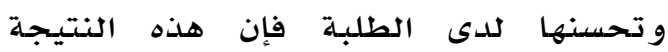

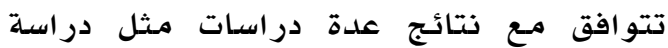

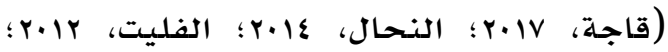

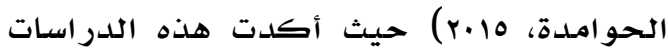

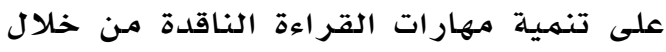

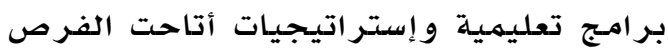

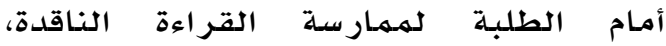
و التدرب على مهار اتها المختلفة.

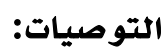
في ضوء مشكلة الدراسة، و النتائج التي تم إلتهات التوصل إليها يمكن التقدم بالتوصيات

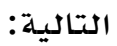

ا. ضرورة تحديد مهارات القراءة الناقدة المناسبة للطلاب واستهداف تنميتها بشكل مباشر و منظم. r. ضرورة تدريب معلمي اللغة العربية

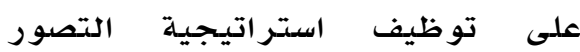
الذهني في تنمية مهارات القراءة الناقدة و المهار ات اللغوية الأخرى. r. توظيف الأسئلة الصفية الموجهة

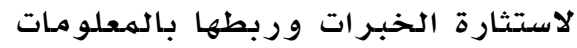
الجديدة المكتسبة من الدرس. ؟. ضرورة تطوير محتوى تعليم القراءة

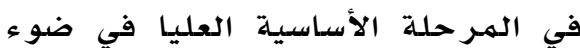


كلأبحاث (العلوم الإنسانية)، بr(q)، IqV9.$Y \cdot T$

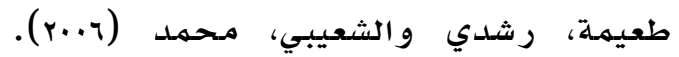
تعليم القراءة والأدب، الطبعة الأولى، لقدي، القاهرة: دار الفكر العربي.

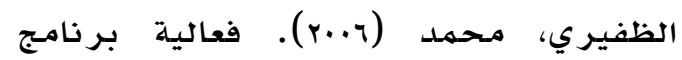
مقترح في تنمية مهارات القراءة الناقدة لدى طلاب كلية التربية جامعة الكويت تخصص اللغة العربية، مجلة القراءة و المعر فة، العدد الواحد و الخمسون.

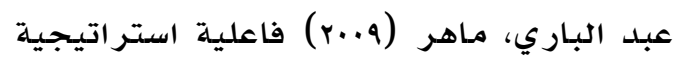

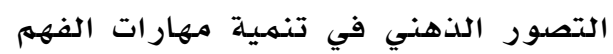

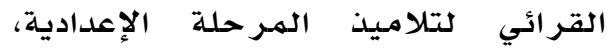
دراسات في المناهج وطرق التدريس، التهرئ،

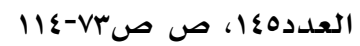

عبد الوهاب، مروى (ج...r). أثر تنمية مهارة

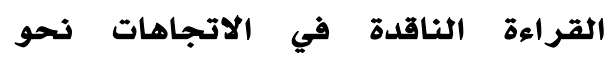
القراءة لدى تلاميذ المرحلة الإعدادية،

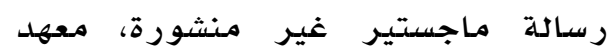
الدر اسـات التربوية، جامعة القاهرة.

العقيلي، عبد المحسن (r/r). فاعلية برنامج تدريبي قائم على استراتيجية التصور الذهني في تنمية مستويات فهم المقروء

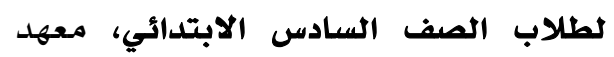

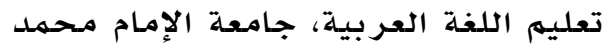

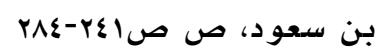
عون، فاضل و العطار، زيد (عا.ب). فاعلية

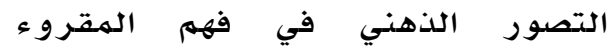
والتفكير الإبداعي لدى طالبات الصف

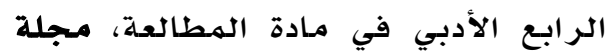
كلية التربية الأساسية للعلوم التربوية الادبية

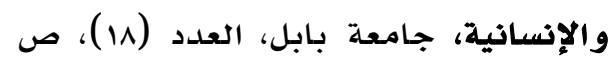
ص و

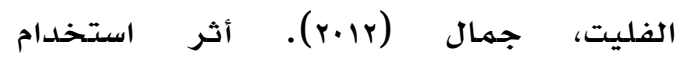
استراتيجية الأسئلة التقويمية في تنمية

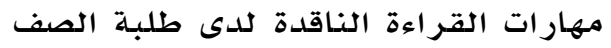
العاشر ، مجلة الزيتونة للعلوم الإنسانية،

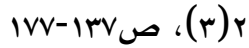

آل جميل، يسرية (؟..r). فعالية برنامج مقترح لاستخدام مراكز مصادر التعلم

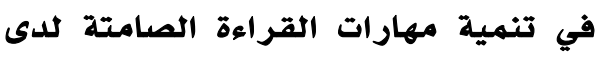
كل من التلاميذ المتفوقين والضعاف

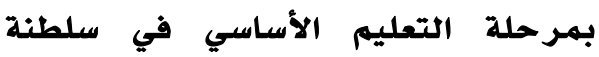
عمان، رسالة دكتوراه، معهد البحوث فئي و الدر اسـات العربية.

البلوشي، نوال وعثمان، محمد (r.r). مستوى تمكن طلبة الصف العاشر

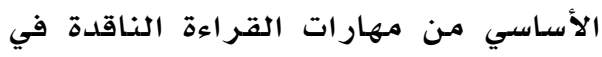

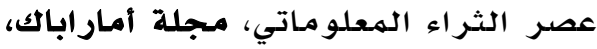

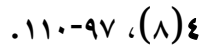

البوهي، حنفي (r.r.r). برنامج لتنمية أداء

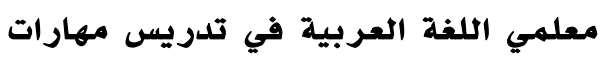
القراءة الناقدة وفعاليته في تنمية هذه

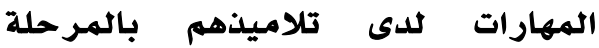
الإعدادية، رسالة دكتوراه غير منشورة الهمئه

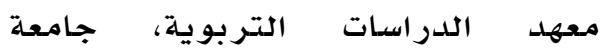

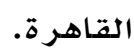

الحوامدة، محمد (10 •r). فاعلية إستراتيجية قائمة على التفكير في تنمية مهارات

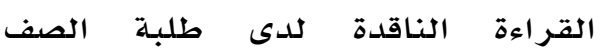

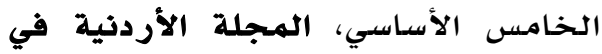

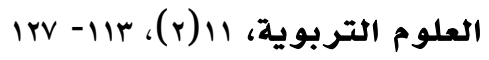

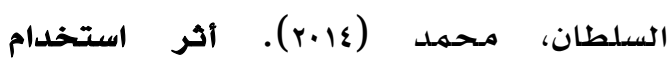

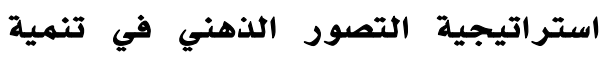
مستويات فهم المقروء لطلاب لمتعلمي

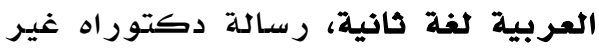

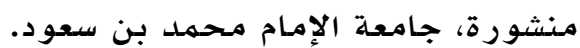

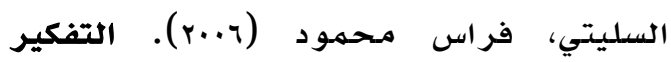
الناقد وإستراتيجية التعلم التعاوني في في لوني تدريس المطالعة، طا، إربد، الأردن: عالم الكتب الحديث. السليتي، فراس ومقدادي، فؤاد (rا.r). أثر

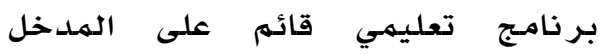
الوظيفي في تحسين مهارات القراءة

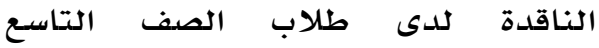
الأساسي في الأردن، مجلة جامعة النجاح 


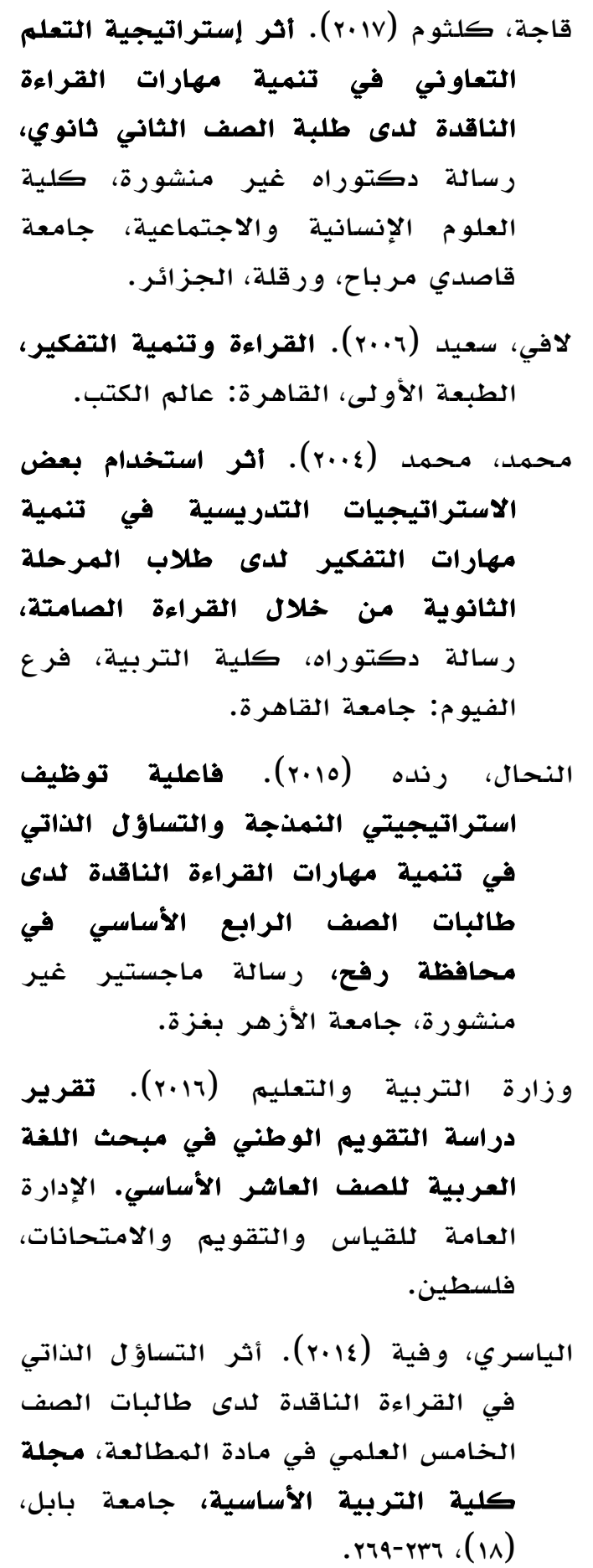

